\title{
Unraveling the Photodynamic Activity of Cationic Benzoporphyrin-Based Photosensitizers against Bladder Cancer Cells
}

\author{
Ana T. P. C. Gomes 1,2,3,4,*iD, M. Graça P. M. S. Neves ${ }^{1} \mathbb{D}$, Rosa Fernandes ${ }^{2,3}\left(\mathbb{D}\right.$, Carlos F. Ribeiro ${ }^{2,3}$,

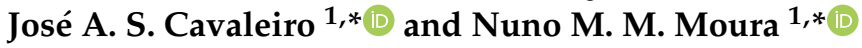 \\ 1 LAQV-REQUIMTE, Department of Chemistry, University of Aveiro, 3810-193 Aveiro, Portugal; gneves@ua.pt \\ 2 Coimbra Institute for Clinical and Biomedical Research (iCBR), Faculty of Medicine, University of Coimbra, \\ 3000-548 Coimbra, Portugal; rcfernandes@fmed.uc.pt (R.F.); cribeiro@fmed.uc.pt (C.F.R.) \\ 3 Center for Innovative Biomedicine and Biotechnology (CIBB), University of Coimbra, \\ 3004-504 Coimbra, Portugal \\ 4 Center for Interdisciplinary Research in Health (CIIS), Faculty of Dental Medicine, \\ Universidade Católica Portuguesa, 3504-505 Viseu, Portugal \\ * Correspondence: ana.peixoto@ua.pt (A.T.P.C.G.); jcavaleiro@ua.pt (J.A.S.C.); nmoura@ua.pt (N.M.M.M.); \\ Tel.: +351-234-370-717 (J.A.S.C.)
}

Citation: Gomes, A.T.P.C.; Neves, M.G.P.M.S.; Fernandes, R.; Ribeiro, C.F.; Cavaleiro, J.A.S.; Moura, N.M.M. Unraveling the Photodynamic Activity of Cationic

Benzoporphyrin-Based

Photosensitizers against Bladder Cancer Cells. Molecules 2021, 26, 5312. https://doi.org/10.3390/molecules 26175312

Academic Editors: Tiziana Pivetta and Sarah Vascellari

Received: 31 July 2021

Accepted: 26 August 2021

Published: 1 September 2021

Publisher's Note: MDPI stays neutral with regard to jurisdictional claims in published maps and institutional affiliations.

Copyright: (c) 2021 by the authors. Licensee MDPI, Basel, Switzerland. This article is an open access article distributed under the terms and conditions of the Creative Commons Attribution (CC BY) license (https:// creativecommons.org/licenses/by/ $4.0 /)$.

\begin{abstract}
In this study, we report the preparation of new mono-charged benzoporphyrin complexes by reaction of the appropriate neutral benzoporphyrin with $\left(2,2^{\prime}\right.$-bipyridine)dichloroplatinum(II) and of the analogs' derivatives synthesized through alkylation of the neutral scaffold with iodomethane. All derivatives were incorporated into polyvinylpyrrolidone (PVP) micelles. The ability of the resultant formulations to generate reactive oxygen species was evaluated, mainly the singlet oxygen formation. Then, the capability of the PVP formulations to act as photosensitizers against bladder cancer cells was assessed. Some of the studied formulations were the most active photosensitizers causing a decrease in HT-1376 cells' viability. This creates an avenue to further studies related to bladder cancer cells.
\end{abstract}

Keywords: benzoporphyrin; photosensitizer; platinum complexes; cancer; photodynamic therapy

\section{Introduction}

Cancer is a broad term that defines a group of diseases that can develop almost anywhere in the body, induced by the uncontrolled overgrowth of abnormal cells resulting in DNA mutations and consequently to the destruction of normal tissues. Malignant disorders are the second leading cause of death worldwide [1,2].

Currently, the most used treatment approaches are based on surgical resection of the tumoral mass, radio-, immuno-, and chemotherapy. However, these treatments display several disadvantages, such as severe radiation damage, limited applicability, lack of specificity, and severe side effects [2].

Concerning the chemotherapeutic approach, platinum-based drugs are the most used drugs against solid tumors such as bladder, testicular, ovarian, lung, neck, or head [3-6]. The mechanism of action of platinum-based drugs is based on their capability to bind DNA strands, which avoids the DNA strand from unzipping, by blocking the replication process, having as a consequence the malignant cell death [7-11].

In 1978, cisplatin was the first FDA-approved platinum-based drug to be used as an anticancer agent. After this milestone, other platinum-based drugs, namely carboplatin and oxaliplatin, were developed and also approved throughout the world [3,12]. Some others have regulatory approval only in some countries (e.g., nedaplatin, miriplatin, loboplatin, or heptaplatin) or are currently under clinical trials $[9,13]$. Despite the wide use of platinumbased drugs, the treated patients experienced severe side effects related to their poor 
selectivity for cancer cells. Among them are hematological and gastrointestinal toxicity, neuro-, nephro-, hepato-, or cardiotoxicity. However, intrinsic or acquired resistance cancer cells to platinum-based drugs is the major drawback related to the use of this class of compounds $[3,7,8,11]$.

The scientific and medical communities are developing efforts to find efficient alternatives to chemotherapy as well as platinum-based drugs. Photodynamic therapy (PDT) is pointed out as one of the most promising approaches to be used for the treatment of malignant diseases $[14,15]$. PDT is a two-stage treatment that relies on the combined action of a photosensitizer (PS), molecular oxygen, and light. The PS is excited by light at a specific wavelength to an excited singlet state and by intersystem crossing to an excited triplet state that in the presence of dioxygen generates reactive oxygen species (ROS) by two mechanisms. The type I mechanism is promoted by electron transfer leading to radicals or radical ions species, while the type II mechanism involves energy transfer from PS to molecular oxygen producing singlet oxygen $\left({ }^{1} \mathrm{O}_{2}\right)$, pointed out as the prevalent process [16-19]. PDT displays various advantages when compared with chemotherapy; the PS is a non-toxic drug in the absence of light, is a non-invasive therapeutic procedure, and displays high selectivity for cancer cells and reduced long-term morbidity and resistance [16,20-23]. Moreover, this approach can be extended to non-oncological diseases, as well as non-clinical targets, including the photoinactivation of microorganisms [24-29].

Porphyrinoids are a class of compounds with distinctive structural, photochemical, and photophysical properties [30] to be used for a wide range of applications such as (chemo)sensors [31-35], (photo)catalysts [36-41], environmental protection [42-44], dyes for solar cells [45-48], and as PSs in medicine [21,49-53]. Regarding the latter use, porphyrinoids exhibit suitable features such as chemical and structural stability, good ${ }^{1} \mathrm{O}_{2}$ generation capabilities, high fluorescence quantum yields, absorbance in the visible region of the electronic spectrum, no dark toxicity, and high affinity for cancer cells making them the most exploited class of compounds as PSs for PDT [15,54].

Concerning the modification of porphyrins and related compounds with platinum(II), most of the modifications reported in the literature describe the metalation of the tetrapyrrolic core with $\mathrm{Pt}(\mathrm{II})$ leading to the corresponding metalloporphyrinoid [55-66]. A literature survey also shows a considerable number of papers describing the preparation of porphyrinplatinum complexes by modification of peripheral moieties at meso positions, mainly by attachment of cyclometalated platinum units to pyridyl moieties [20,59,67-73]. Analogue synthetic approaches were also reported to modify corroles [74,75] and phthalocyanines [76-80].

Relatively less attention was paid to the preparation of porphyrin-platinum complexes throughout $\beta$-pyrrolic positions. Most of these studies were reported by Osuka's group and involved the introduction of pyridyl units via metal-catalyzed cross-coupling reactions and further metalation with Pt(II) or Pt(IV) [81-85]. However, to the best of our knowledge, the preparation of benzoporphyrin-platinum complexes at the $\beta$-pyrrolic positions, namely at the isoindole-type unit, remains unexplored.

Here, we describe the preparation of new mono-cationic benzoporphyrin complexes by reaction of the appropriate pyridyl benzoporphyrin scaffold with (2,2'-bipyridine) dichloroplatinum(II). With this strategy, it was intended to conjugate the antitumor activity of platinum derivatives with the well-known phototoxicity properties of porphyrin macrocycles. Moreover, positively charged analogues were also prepared through the $\mathrm{N}$-alkylation of the benzoporphyrins pyridyl units with iodomethane to compare their properties/activity relationship. All the mono-charged synthesized benzoporphyrin derivatives were incorporated into polyvinylpyrrolidone (PVP) micelles, and the photosensitizer capability of the obtained formulations was evaluated and compared against a human bladder cancer cell line derived from transitional cell carcinoma. The PDT treatment of this type of cancer can benefit from the easy light delivery via insertion of a light source into urethra [86]. 


\section{Results and Discussion}

\subsection{Synthesis}

The synthesis of the positively monocharged benzoporphyrin derivatives 2 and 3 required the previous preparation of the scaffolds $\mathbf{1} \mathbf{a}, \mathbf{b}$ following procedures already reported by us. Briefly, 2-formyl-5,10,15,20-tetraphenylporphyrin reacts with the adequate 3- or 4-acetylpyridine in the presence of $\mathrm{NH}_{4} \mathrm{OAc}$ and catalytic amounts of $\mathrm{La}(\mathrm{OTf})_{3}$ in refluxing toluene for $4 \mathrm{~h}$, under $\mathrm{N}_{2}$ atmosphere [87,88].

Then, the precursors $\mathbf{1} \mathbf{a}, \mathbf{b}$ reacted with $\left(2,2^{\prime}\right.$-bipyridine)dichloroplatinum(II) in refluxing $\mathrm{CHCl}_{3} / \mathrm{MeOH}$ (2:1) mixture for $24 \mathrm{~h}$. After purification by column chromatography, the expected $\mathbf{2 a}$ or $\mathbf{2 b}$ derivatives were obtained in 68 and $87 \%$ yield, respectively. In the synthesis of the benzoporphyrin-platinum complex $\mathbf{2 a}$, it was recovered $18 \%$ of the starting benzoporphyrin 1a. The lower reactivity of derivative 1a and, consequently, the low yield obtained for $2 \mathbf{a}$ are probably related with a hindrance effect due to the bulkiness of the (2,2'-bipyridine)chloroplatinum(II) moiety and the proximity of the nitrogen atom of the pyridyl unit to the benzoporphyrin core. An extension of the reaction time from 24 to $48 \mathrm{~h}$ led to a slight improvement in the yield of benzoporphyrin-platinum complex $2 \mathrm{a}$ to $72 \%$.

It is worth noting that all the attempts to prepare the analog benzoporphyrin-platinum complex bearing a 2-substituted pyridyl moiety failed, probably due to an even higher steric hindrance effect induced by the bulkiness of the (2,2'-bipyridine)chloroplatinum(II) moiety and the proximity of the pyridyl nitrogen atom with the benzoporphyrin core.

Compounds $\mathbf{3 a}$ and $\mathbf{3 b}$ were prepared in 97 and $98 \%$ yield, respectively, from the corresponding neutral derivative $\mathbf{1} \mathbf{a}, \mathbf{b}$ by alkylation reaction with iodomethane in DMF at $40{ }^{\circ} \mathrm{C}$ for $24 \mathrm{~h}$ (Scheme 1). This is a typical and well-established protocol to prepare porphyrinoids bearing pyridinium moieties and, once again, it revealed to be effective for preparing the benzoporphyrin derivatives $\mathbf{3 a}, \mathbf{b}$.

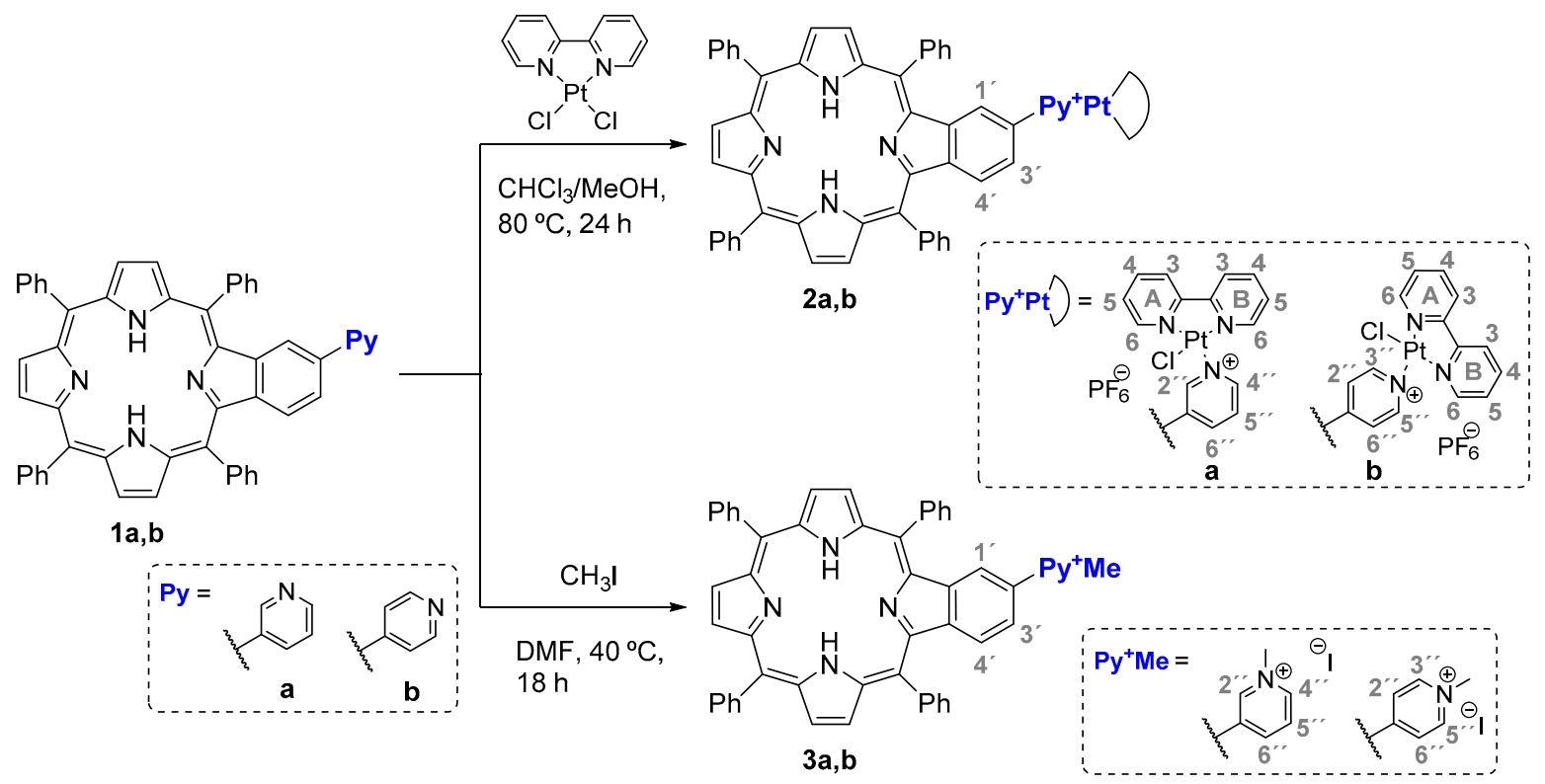

Scheme 1. Synthetic approach to prepare benzoporphyrins $\mathbf{2} \mathbf{a}, \mathbf{b}$ and $\mathbf{3 a}, \mathbf{b}$.

The structures of compounds $\mathbf{2} \mathbf{a}, \mathbf{b}$ and $\mathbf{3} \mathbf{a}, \mathbf{b}$ were confirmed by NMR spectroscopy and mass spectrometry data (see Figures S1-S22. The mass spectra of the mono-charged benzoporphyrin derivatives $\mathbf{2} \mathbf{a}, \mathbf{b}$ and $\mathbf{3} \mathbf{a}, \mathbf{b}$ exhibit the $m / z$ peak corresponding to the $[\mathrm{M}+2 \mathrm{H}]^{+}$or $[\mathrm{M}+2 \mathrm{H}]^{+\bullet}$ molecular ion. However, it is important to point out that, for all the compounds synthesized, the corresponding $[\mathrm{M}+2 \mathrm{H}]^{+}$and $[\mathrm{M}+2 \mathrm{H}]^{+\bullet}$ species are formed in the gas phase due to the reduction in one of the $\beta$-pyrrolic positions. Similar results were already observed by us in a previous publication [89]. 
The ${ }^{1} \mathrm{H}$ NMR analysis of the derivatives $\mathbf{2} \mathbf{a}, \mathbf{b}$ and $\mathbf{3} \mathbf{a}, \mathbf{b}$ supports also the proposed structures with the resonances of six $\beta$-pyrrolic protons appearing in the aromatic region, between $\delta 8.98$ and $\delta 8.60 \mathrm{ppm}$. In all the ${ }^{1} \mathrm{H}$ NMR spectra, the distinguishing singlet at ca. $\delta-2.7 \mathrm{ppm}$ generated by the resonance of the $\mathrm{N}-\mathrm{H}$ protons from the free-base benzoporphyrin core is also observed.

The ${ }^{1} \mathrm{H}$ NMR spectra of compound $\mathbf{3} \mathbf{a}, \mathbf{b}$ show a singlet at around $\delta 4.67 \mathrm{ppm}$ generated by the resonances of the methyl groups' protons confirming the formation of the pyridinium moiety. All the remaining signals generated by the resonances of the protons from the benzoporphyrin moieties, as well as from the phenyl ring at the meso-positions appear in the aromatic region, being the most deshielded signals generated by the protons near the nitrogen atom at the pyridinium unity.

In the ${ }^{1} \mathrm{H}$ NMR of compounds $\mathbf{2} \mathbf{a}, \mathbf{b}$, the most deshielded signals (ca. $9.6 \mathrm{ppm}$ ) are due to the resonances of the protons from the 6 positions of the 2,2'-bipyridine unit, while the protons from the pyridyl units are shielded by the presence of the platinum core when compared with the ones from the neutral precursors. The signals generated by the remaining protons from the benzoporphyrin core are not significantly affected by the $2,2^{\prime}-$ bipyridine)chloroplatinum(II) unit and display similar chemical shifts to the ones observed for the corresponding $\mathbf{3} \mathbf{a}, \mathbf{b}$ derivatives.

The absorption, steady-state fluorescence emission, and excitation spectra of the new derivatives were recorded in $N, N$-dimethylformamide (DMF) solution at $298 \mathrm{~K}$. The UV-Vis spectra of compounds $\mathbf{2} \mathbf{a}, \mathbf{b}$ and $\mathbf{3} \mathbf{a}, \mathbf{b}$ were not significantly affected by the modification performed into the benzoporphyrinic ring, presenting the typical features of free-base porphyrin derivatives due to $\pi-\pi^{*}$ transitions [90-92]. Both series $\mathbf{2} \mathbf{a}, \mathbf{b}$ and $\mathbf{3} \mathbf{a}, \mathbf{b}$ exhibit a strong Soret band at ca. $427 \mathrm{~nm}$ assigned to allowed $S_{0} \rightarrow S_{2}$ transitions and two $Q$ bands at approximately 520 and $595 \mathrm{~nm}$ due to $S_{0} \rightarrow S_{1}$ transitions. Additionally, absorption bands centered from 282 to $324 \mathrm{~nm}$ were observed for derivatives $\mathbf{2 a}, \mathbf{b}$ due to the ligand to metal charge transfer (LMCT) transition from the bipyridine moiety to the platinum ion. The fluorescence emission spectra of compounds $\mathbf{2}$ and $\mathbf{3}$ obtained after excitation at approximately $595 \mathrm{~nm}$ present two bands centered at ca. 660 and $720 \mathrm{~nm}$ (Table 1, Figures $1 \mathrm{~A}, \mathrm{~B}$ and $\mathrm{S} 23 \mathrm{~A}, \mathrm{~B})$.
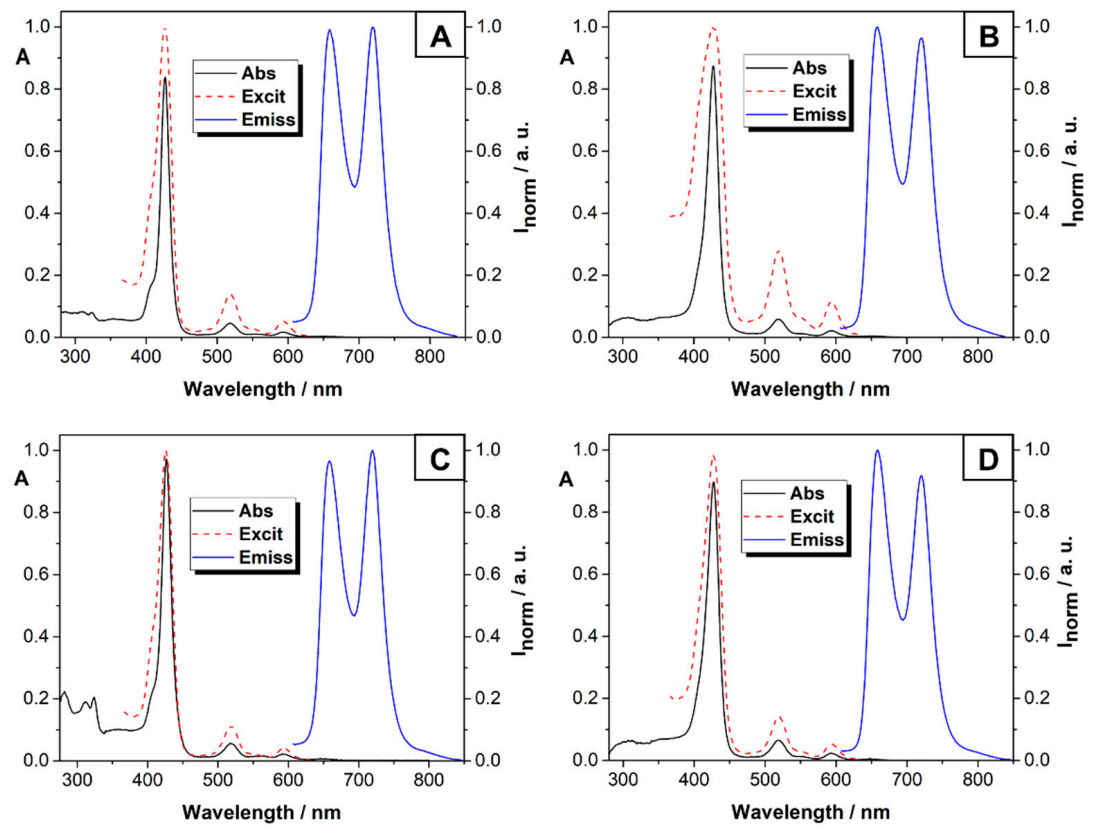

Figure 1. Absorption and normalized emission and excitation spectra of 2a (A), 3a (B), PVP-2a (C) and PVP-3a (D) in DMF at $298 \mathrm{~K} .\left([2 \mathbf{a}]=[3 \mathbf{a}]=[\mathbf{P V P}-2 \mathbf{a}]=[\mathbf{P V P}-3 \mathbf{a}]=3.0 \times 10^{-6} \mathrm{M}\right.$; $\lambda_{\text {ex2a }}=\lambda_{\text {ex3a }}=593 \mathrm{~nm}$ and $\lambda_{\text {exPVP-2a }}=\lambda_{\text {exPVP-3a }}=595 \mathrm{~nm} ; \lambda_{\text {em2a }}=\lambda_{\text {em3a }}=659 \mathrm{~nm}$ and $\lambda_{\text {emPVP-2a }}=\lambda_{\text {emPVP-3a }}=658 \mathrm{~nm}$ ). 
Table 1. Photophysical data of $\mathbf{2} \mathbf{a}, \mathbf{b}$ and $\mathbf{3} \mathbf{a}, \mathbf{b}$ and PVP-PS formulations PVP-2a,b and PVP-3a,b in DMF at $298 \mathrm{~K}$.

\begin{tabular}{|c|c|c|c|c|}
\hline Compd & $\lambda_{\max }(\mathrm{nm}): \log \varepsilon$ & $\lambda_{\mathrm{em}}(\mathrm{nm})$ & Stokes Shift $\left(\mathrm{cm}^{-1}\right)$ & $\Phi_{\mathrm{F}}$ \\
\hline \multirow[b]{6}{*}{ 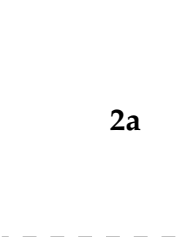 } & $286: 4.44$ & \multirow{6}{*}{659,719} & \multirow{6}{*}{$151,515.2$} & \multirow{6}{*}{0.07} \\
\hline & $312: 4.43$ & & & \\
\hline & $323: 4.45$ & & & \\
\hline & 427:5.45 & & & \\
\hline & 518:4.01 & & & \\
\hline & 593:3.57 & & & \\
\hline \multirow[t]{3}{*}{-------} & $--\overline{3} \overline{12}: \overline{4} . \overline{6} 7^{-}$ & \multirow{4}{*}{660,720} & \multirow{4}{*}{$3,151,515.2$} & \multirow{4}{*}{0.06} \\
\hline & $324: 4.43$ & & & \\
\hline & 427:5.49 & & & \\
\hline & $520: 4.32$ & & & \\
\hline \multirow{2}{*}{\multicolumn{4}{|c|}{ 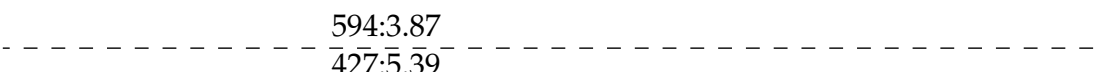 }} & \\
\hline & & ----- & ----------- & ----- \\
\hline \multirow[t]{2}{*}{$3 a$} & 518:4.07 & \multirow[t]{2}{*}{659,720} & $151,515.2$ & \multirow[t]{2}{*}{0.06} \\
\hline & 593:3.72 & & $-\ldots-\ldots$ & \\
\hline$a_{-1}$ & $\overline{4} 2 \overline{9}: \overline{5} . \overline{0} 6-$ & ----- & $6 \pi a^{2}$ & \multirow{3}{*}{0.05} \\
\hline \multirow{2}{*}{$3 b$} & 522:4.15 & \multirow{2}{*}{662,723} & \multirow{2}{*}{$153,846.2$} & \\
\hline & 597:3.74 & & & \\
\hline \multirow{6}{*}{ PVP-2a } & $282: 4.87$ & \multirow{6}{*}{658,719} & \multirow{6}{*}{$158,730.2$} & \multirow{6}{*}{0.07} \\
\hline & $312: 4.80$ & & & \\
\hline & $324: 4.84$ & & & \\
\hline & $426: 5.45$ & & & \\
\hline & 518:3.95 & & & \\
\hline & 595:3.52 & & & \\
\hline & $\overline{2} \overline{5}: \overline{4} \cdot \overline{5} 3^{-}$ & \multirow{4}{*}{661,720} & \multirow{4}{*}{$149,253.7$} & \multirow{4}{*}{0.04} \\
\hline \multirow[b]{6}{*}{------} & $309: 4.57$ & & & \\
\hline & $323: 4.56$ & & & \\
\hline & 426:5.08 & & & \\
\hline & 519:4.04 & & & \\
\hline & 594:3.58 & & & \\
\hline & $\overline{4} \overline{27}: \overline{4} . \overline{9} 9^{--}$ & ---- & ---------- & ----- \\
\hline PVP-3a & $520: 3.82$ & \multirow[t]{2}{*}{658,720} & \multirow{2}{*}{$158,730.2$} & 0.05 \\
\hline & 595:3.47 & & & $\ldots$ \\
\hline & $-\overline{4} \overline{28}: \overline{3} \cdot \overline{9} 1^{-}$ & & 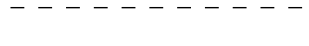 & \\
\hline PVP-3b & $523: 3.91$ & 662,725 & $153,846.2$ & 0.04 \\
\hline & 597:3.52 & & & \\
\hline
\end{tabular}

The resemblance between the absorption and excitation spectra rules out the presence of emissive impurities. The large Stokes shift (ca. $66 \mathrm{~nm}$ ) displayed by both prepared series of benzoporphyrin derivatives are indicative of a change in the electronic nature of the excited state compared with that of the ground state. The fluorescence quantum yields $\left(\Phi_{\mathrm{F}}\right)$ determined by the internal reference method with respect to a solution of 5,10,15,20tetraphenylporphyrin (TPP) in DMF as standard $\left(\Phi_{\mathrm{F}}=0.11\right)[93,94]$ are shown in Table 1 . The $\Phi_{\mathrm{F}}$ values range from 0.05 to 0.07 , and no noticeable differences were induced by the presence of the cyclometalated (2,2'-bipyridine)platinum(II) moieties or the methyl groups.

\subsection{Incorporation into PVP Micelles}

Benzoporphyrin derivatives 2 and 3 were used to prepare polyvinylpyrrolidone (PVP) formulations aiming to avoid aggregation phenomena in aqueous medium due to their low hydrophilic character (miLog P: 8.45-9.91) [95]. This is a low-cost approach that requires the dissolution of both PS and $\mathrm{N}$-vinylpyrrolidone (VPD) in $\mathrm{CHCl}_{3}$ solution, stirring the resulting mixture for $2 \mathrm{~h}$ at room temperature, and then solvent removal under a nitrogen flow. The resulting residue, after being maintained for $48 \mathrm{~h}$ at $40{ }^{\circ} \mathrm{C}$, was dissolved in water and submitted to dialysis affording the expected PVP-PS formulations PVP-2a,b and PVP-3a,b. It is worth noting that the PVP-PS formulations prepared retained the 
photophysical features previously discussed for PS $\mathbf{2}$ and $\mathbf{3}$ without noticed changes due to their incorporation into PVP micelles (Table 1, Figures 1C,D and S23C,D).

VPD was selected as the monomer to prepare PVP formulations due to their already reported features, namely, pharmacokinetic and pharmacological properties, non-toxicity, and water-solubility of the obtained micelles [96]. This strategy allows to improve the hydrophilicity of biologically active drugs and is being efficiently used to solubilize neutral porphyrin-base PS in water with positive effects in photodynamic processes [97-100]. Moreover, this carrier demonstrated to be non-toxic for both normal and cancer cells after PDT treatment [100]. However, to the best of our knowledge, this approach has not been used with benzoporphyrin-type derivatives.

\subsection{Photostability and Singlet Oxygen Generation}

Photostability is a relevant parameter to evaluate the PS potential to be used in photodynamic processes such as PDT. The photostability assays for PVP-PS formulations PVP-2a,b and PVP-3a,b were performed in PBS by monitoring the Soret band decay $\left(\lambda_{\max }=425 \mathrm{~nm}\right)$ after irradiation with white light at an irradiance of $20 \mathrm{~mW} \cdot \mathrm{cm}^{-2}$ for different irradiation periods. After $30 \mathrm{~min}$ of irradiation, formulations PVP-2b and PVP$\mathbf{3 a}, \mathbf{b}$ showed a Soret band absorption decay ranging from 11 to $16 \%$, while, for PVP-2a, the decrease was $28 \%$ (Table S1). As such, it is possible to conclude that the two synthetic strategies used to modify the benzoporphyrin core and the incorporation of the obtained benzoporphyrin derivatives into PVP micelles allowed to afford PVP formulations with adequate photostability.

Besides photostability, another relevant feature for a PS to be used in PDT is its capability to generate ROS, namely, singlet oxygen $\left({ }^{1} \mathrm{O}_{2}\right)$ [101]. The generation of ${ }^{1} \mathrm{O}_{2}$ by the PVP-PS formulations was qualitatively determined by monitoring at $415 \mathrm{~nm}$, the photooxidation of the ${ }^{1} \mathrm{O}_{2}$ quencher 1,3-diphenylisobenzofuran (DPiBF) to the colorless $o$-dibenzoylbenzene, after the Diels-Alder-like reaction [102-104]. The irradiations of each PVP-PS formulation in DMF and in the presence of dioxygen were performed at a fluence of $11 \mathrm{~mW} \cdot \mathrm{cm}^{-2}$ and the results obtained from the DPiBF time-dependent photodecomposition are summarized in Figure 2.

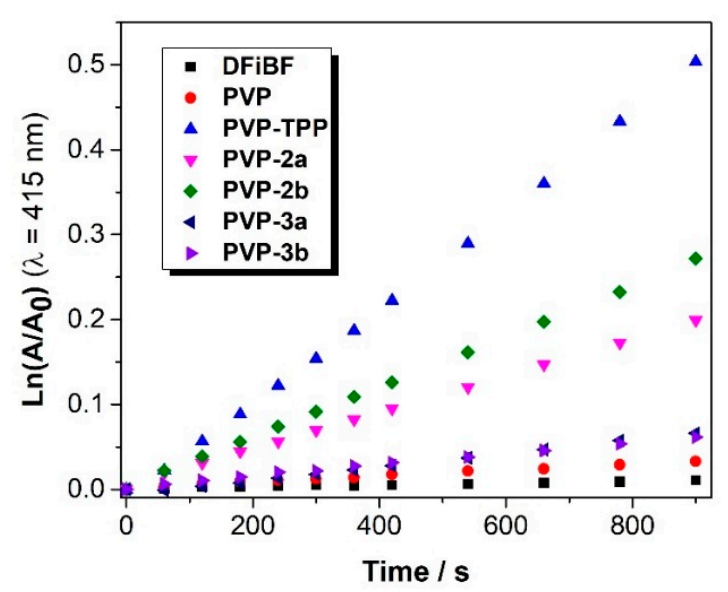

Figure 2. Time-dependent photodecomposition of DPiBF at $50 \mu \mathrm{M}$ photosensitized by PVP-PS formulations PVP-2a,b, PVP-3a,b, and PVP-TPP at $0.5 \mu \mathrm{M}$ upon irradiation with red light $(630 \pm 20 \mathrm{~nm})$ at an irradiation of $11 \mathrm{~mW} \cdot \mathrm{cm}^{-2}$.

It is worth noting that, for these assays, a PVP-TPP formulation was prepared to be used as reference, since 5,10,15,20-tetraphenylporphyrin (TPP) is pointed out as a good singlet oxygen generator [105].

The PVP-2a, $\mathbf{b}$ formulations showed to be better ${ }^{1} \mathrm{O}_{2}$ generators than PVP-3a,b formulations, despite both series displaying worse capability than the one presented by the PVP-TPP formulation. The capability of PVP-3a, $\mathbf{b}$ formulations is $10 \%$ of the one exhib- 
ited by the reference and is not significantly affected by the position of the charge in the pyridinium unit. The ability of the PVP-2a and PVP-2b formulations to produce ${ }^{1} \mathrm{O}_{2}$ is 60 and $45 \%$ lower when compared with the reference, respectively, but even so, it is 4 - to 5 -fold higher than the ones presented by the PVP-3a, b formulations. Yet, for the PVP-2a, $\mathbf{b}$ formulations, the position of the charge and the (2,2'-bipyridine)chloroplatinum(II) unit influences the PS production of ${ }^{1} \mathrm{O}_{2}$, with $\mathbf{2 b}$ being the one with the better yield of ${ }^{1} \mathrm{O}_{2}$.

From the analysis of Figure 2, it is obvious that the absorbance of DPiBF, when irradiated in the absence of a PS, remains almost unchanged, as well as in the presence of just PVP. These results revealed the potential of the PVP-PS formulations prepared to be used in PDT and prompted us to evaluate their efficiency as PSs against bladder cancer cells.

\section{Photodynamic Activity of PVP-2a,b and PVP-3a,b Formulations against Human Bladder Cancer Cells}

\subsection{Cellular Uptake of PVP-2a, $\mathbf{b}$ and PVP-3a, $\mathbf{b}$ Formulations}

The ability of PSs PVP-2a, $\mathbf{b}$ and PVP-3a, $\mathbf{b}$ for being internalized by cancer cells was spectrofluorometrically evaluated, using a human bladder cancer cell line derived from transitional cell carcinoma (HT-1376 cell line). Thus, HT-1376 cells were incubated in the dark with increasing concentrations of each PVP formulation $(2.5,5.0,10.0$, and $12.5 \mu \mathrm{M})$ in PBS for 2 and $4 \mathrm{~h}$. The results for the intracellular uptake of PVP-2a, $\mathbf{b}$ and PVP-3a,b are presented in Figure 3 and show that the internalization of the PVP formulations in HT-1376 cell line is, in general, concentration and time-dependent, reaching the maximum after $4 \mathrm{~h}$ of incubation. It is also evident that PVP-3a formulation presents the highest intracellular accumulation, $24.5 \pm 2.24$ and $22.6 \pm 3.17 \mathrm{nmol}$ of PS $/ \mathrm{mg}$ of protein, for 10 and $12.5 \mu \mathrm{M}$, respectively, and after $4 \mathrm{~h}$. Although absolute values are lower, the maximum intracellular accumulation also occurs after $4 \mathrm{~h}$ incubation for formulations PVP-3b and PVP-2a,b.
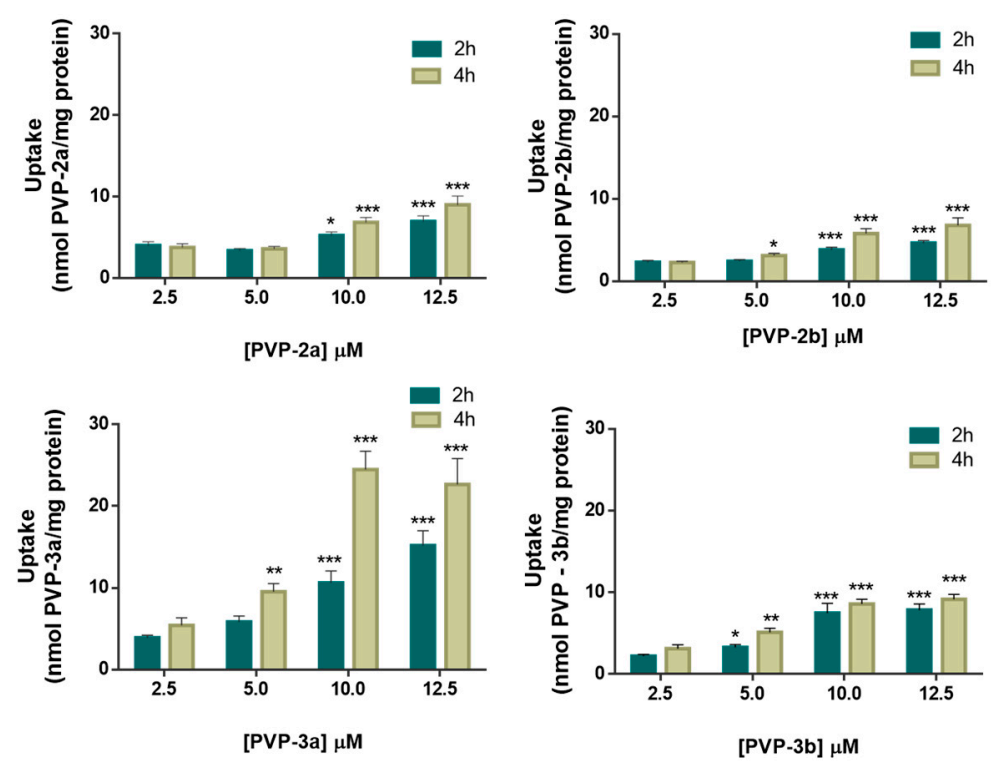

Figure 3. Intracellular uptake of formulations PVP-2a,b and PVP-3a,b by HT-1376 cells. Data are the mean \pm S.D. of at least three independent experiments performed in triplicates: ${ }^{*}(p<0.05)$, ** $(p<0.01),{ }^{* * *}(p<0.001)$ significantly different from uptake of PVP formulations at lower concentration.

PVP-2b presents the lowest internalized PS concentration, with $5.77 \pm 0.59$ and $6.78 \pm 0.89 \mathrm{nmol}$ of PS/mg of protein, for 10 and $12.5 \mu \mathrm{M}$, respectively. The intracellular accumulation in HT-1376 cells of PVP-2a and PVP-3b reach the maximum at $10 \mu \mathrm{M}$ after $4 \mathrm{~h}$ of incubation, reaching a value of $9.02 \pm 1.08$ and $9.16 \pm 0.61 \mathrm{nmol}$ of PS/mg of protein. 


\subsection{Cell Viability after PDT Treatment with PVP-2a, $\mathbf{b}$ and PVP-3a,b Formulations}

The photodynamic effect of the PVP-2a, $\mathbf{b}$ and PVP-3a,b formulations was evaluated in bladder cancer cell line HT-1376 at 2.5, 5.0, 10.0, and $12.5 \mu \mathrm{M}$. The cell line was incubated in the dark for $4 \mathrm{~h}$ with the PVP formulations and then irradiated with white light for $40 \mathrm{~min}$ with an irradiance of $20 \mathrm{~mW} \cdot \mathrm{cm}^{-2}$. The cell viability was accessed by the MTT colorimetric assay after $24 \mathrm{~h}$ of PDT protocol. The results obtained are presented in Figure 4, and the IC50 PDT values (for a fluence rate of $20 \mathrm{~mW} \cdot \mathrm{cm}^{-2}$ ) of all formulations are plotted in Table 2.
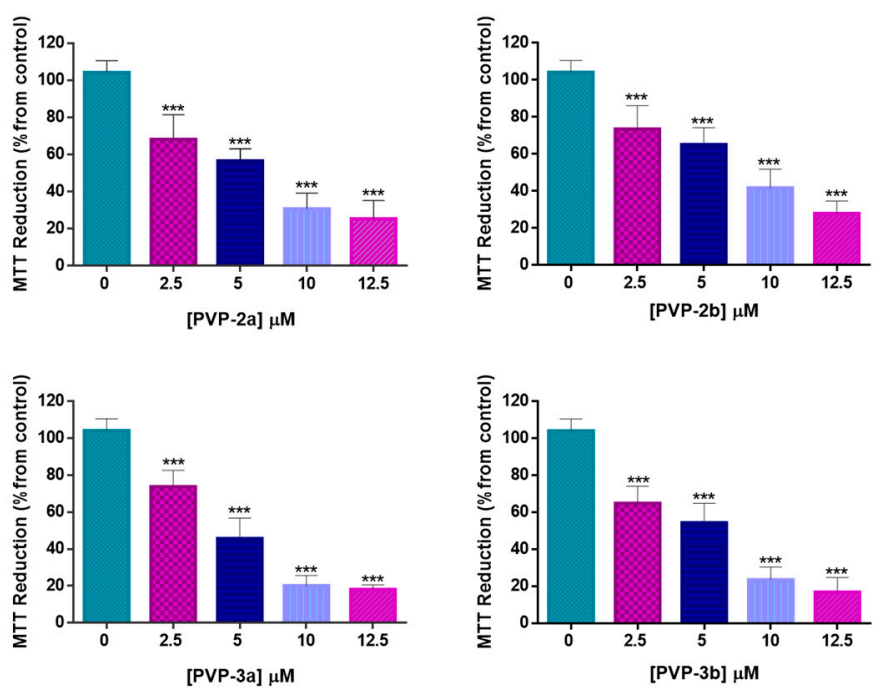

Figure 4. Phototoxic effect of formulations PVP-2a,b and PVP-3a,b in HT-1376 cells. Cells were incubated with the formulations for $4 \mathrm{~h}$ and then irradiated with white light (fluence rate of $20 \mathrm{~mW} \cdot \mathrm{cm}^{-2}$ ) for $40 \mathrm{~min}$. Cytotoxicity was evaluated $24 \mathrm{~h}$ after PDT. Data are the mean value \pm S.D. of at least three independent experiments performed in triplicates: ${ }^{*}(p<0.05),{ }^{* *}(p<0.01),{ }^{* *}(p<0.001)$ compared to MTT reduction (\%) at $24 \mathrm{~h}$ after PDT for control cells (untreated cells).

Table 2. IC50 ${ }_{\mathrm{PDT}}(\mu \mathrm{M})$ values of PVP-2a,b and PVP-3a,b formulations in HT-1376 cell line (for a fluence rate of $\left.20 \mathrm{~mW} \cdot \mathrm{cm}^{-2}\right)$.

\begin{tabular}{cc}
\hline PVP Formulation & IC50 $_{\text {PDT }}{ }^{*}$ \\
\hline PVP-2a & $6.42 \mu \mathrm{M}$ \\
PVP-2b & $8.14 \mu \mathrm{M}$ \\
PVP-3a & $5.58 \mu \mathrm{M}$ \\
PVP-3b & $5.51 \mu \mathrm{M}$
\end{tabular}

* Calculated by extrapolation from the non-linear regression curve MTT reduction (\% from control) vs. $\log$ (concentration).

The results showed that all PVP formulations caused a decrease in the HT-1376 cell viability, being possible to observe that the phototoxicity increased with the PS concentration. PVP-3a,b formulations showed to be the most active PSs causing a decrease in HT-1376 cell viability higher than $80 \%$ for the maximum concentration. This superior efficiency is also proved by their lower IC50 ${ }_{\text {PDT }}$ values (5.58 and $5.51 \mu \mathrm{M}$ for PVP-3a and PVP-3b, respectively). Although also highly efficient, the phototoxicity values of PVP-2a,b formulations were lower, causing a reduction in the HT- 1376 cell viability of around $70 \%$ for the highest concentration. This fact could be explained by the lower PVP-2a,b accumulation inside HT-1376, when compared with the internalization of PVP-3a,b into the bladder cancer cell line.

The same protocol without the irradiation procedure was performed to evaluate the cytotoxic effect of all formulations. As expected, no cytotoxicity was observed in 
cells incubated with PVP-2a,b and PVP-3a,b in the dark for at least $24 \mathrm{~h}$ (data shown in Figure S24).

It is well known that the efficiency of PDT depends on the intrinsic efficacy of the PS, and there are many PS properties that need to be taken into account, such as ${ }^{1} \mathrm{O}_{2}$ generation, aggregation, and photodegradation behavior [106]. Although being the least efficient in the ${ }^{1} \mathrm{O}_{2}$ generation, it is noteworthy that formulations PVP-3a,b were the ones that demonstrated higher photostability and higher internalization into the cancer cell line. The conjugation of these important properties could explain the higher efficiency of these formulations in the decrease in the HT-1376 cell viability after the PDT procedure.

Moreover, it is also important to note that, in this particular case, the insertion of a 2,2'-bipyridine-platinum moiety into the benzoporphyrin macrocycle did not enhance the PDT effect in the cancer cell line.

\section{Materials and Methods}

\subsection{General Remarks}

${ }^{1} \mathrm{H}$ and ${ }^{13} \mathrm{C}$ NMR spectra were recorded on a Bruker Avance 300 spectrometer at $300.13 \mathrm{MHz}$ and a Bruker Avance 500 spectrometer at 500.12 and $125.77 \mathrm{MHz}$, respectively. $\mathrm{CDCl}_{3}$ was used as solvent and tetramethylsilane (TMS) as internal reference. Chemical shifts are expressed in $\delta(\mathrm{ppm})$ and the coupling constants $(J)$ are expressed in Hertz. HRMS were recorded on a VG AutoSpec M mass spectrometer using $\mathrm{MeOH}$ as solvent and 3-nitrobenzyl alcohol (NBA) as matrix. The UV-Vis spectra were recorded on an UV-2501 PC Shimadzu spectrophotometer using DMF as solvent. Fluorescence emission spectra were recorded on a Horiba Jobin-Yvon Fluoromax 3 spectrofluorometer and fluorescence quantum yields of compounds $\mathbf{2} \mathbf{a}, \mathbf{b}$ and $\mathbf{3} \mathbf{a}, \mathbf{b}$ and PVP-PS formulations PVP-2a,b and PVP-3a,b were measured by using a solution of TPP in DMF as a standard $\left(\Phi_{\mathrm{F}}=0.11\right)$. Flash chromatography was carried out using silica gel (230-400 mesh), and preparative thin-layer chromatography was carried out on $20 \times 20 \mathrm{~cm}$ glass plates coated with silica gel ( $1 \mathrm{~mm}$ thick). The reactions were routinely monitored by thin-layer chromatography (TLC) on silica gel precoated F254 Merck plates.

\subsection{Synthesis}

\subsubsection{Synthesis of the Benzoporphyrin Precursors 1}

Precursors $\mathbf{1 a}$ and $\mathbf{1 b}$ were synthesized according to the previous procedures described. The structures of both porphyrin-based PS were confirmed by ${ }^{1} \mathrm{H}-\mathrm{NMR}$ spectroscopy and mass spectrometry, and the data are in accordance with the data reported [87].

\subsubsection{Synthesis of Porphyrin-Platinum(II) Complexes}

(2,2'-Bipyridine)dichloroplatinum(II) $(13.7 \mathrm{mg}, 32.4 \mu \mathrm{mol})$ was added to a solution of the adequate benzoporphyrin $\mathbf{1 a}$ or $\mathbf{1 b}(20 \mathrm{mg}, 27 \mu \mathrm{mol})$ in a $\mathrm{CHCl}_{3} / \mathrm{MeOH}$ mixture $(2: 1,1.5 \mathrm{~mL})$ in a sealed tube. The reaction mixture was stirred at $100{ }^{\circ} \mathrm{C}$ for $24 \mathrm{~h}$. Then, $0.2 \mathrm{M}$ aqueous saturated solution of $\mathrm{KPF}_{6}$ was added to the reaction mixture, and the precipitate obtained, corresponding to the $\mathrm{PF}_{6}{ }^{-}$salt, was filtered, dissolved in $\mathrm{CH}_{2} \mathrm{Cl}_{2}$, and washed with distilled water, and the organic layer was collected. The solvent was evaporated under reduced pressure, and the crude purified by column chromatography using $\mathrm{CH}_{2} \mathrm{Cl}_{2} / \mathrm{MeOH}$ (98:2) as the eluent. The benzoporphyrin-platinum(II) complexes $\mathbf{2 a}$ and $\mathbf{2 b}$ were obtained pure after crystallization from $\mathrm{CH}_{2} \mathrm{Cl}_{2} /$ hexane.

Compound 2a: Yield: 68\%. ${ }^{1} \mathrm{H}$ NMR $\left(500 \mathrm{MHz}, \mathrm{CDCl}_{3}\right): \delta 9.66(1 \mathrm{H}, \mathrm{dd}, J=1.0$ and $5.6 \mathrm{~Hz}, \mathrm{H}-6 \mathrm{~A}), 9.60(1 \mathrm{H}, \mathrm{dd}, J=1.2$ and $5.7 \mathrm{~Hz}, \mathrm{H}-6 \mathrm{~B}), 9.09\left(1 \mathrm{H}, \mathrm{d}, J=2.0 \mathrm{~Hz}, \mathrm{H}-2^{\prime \prime}\right), 8.94$ $(1 \mathrm{H}, \mathrm{d}, J=5.0 \mathrm{~Hz}, \mathrm{H}-\beta), 8.89(1 \mathrm{H}, \mathrm{d}, J=5.0 \mathrm{~Hz}, \mathrm{H}-\beta), 8.87(1 \mathrm{H}, \mathrm{d}, J=5.0, \mathrm{H}-\beta), 8.81-8.79$ $\left(1 \mathrm{H}, \mathrm{m}, \mathrm{H}-4^{\prime \prime}\right), 8.75-8.70(3 \mathrm{H}, \mathrm{m}, \mathrm{H}-\beta), 8.43-8.39$ (2H, m, H-6" and H-o-Ph), $8.36(1 \mathrm{H}, \mathrm{d}$, $J=8.0 \mathrm{~Hz}, \mathrm{H}-\mathrm{o}-\mathrm{Ph}), 8.32-8.28(2 \mathrm{H}, \mathrm{m}, \mathrm{H}-3 \mathrm{~B}$ and $\mathrm{H}-\mathrm{o}-\mathrm{Ph}), 8.24-8.16(6 \mathrm{H}, \mathrm{m}, \mathrm{H}-3 \mathrm{a}, \mathrm{H}-4 \mathrm{~B}$ and $\mathrm{H}-\mathrm{o}-\mathrm{Ph}), 8.09(1 \mathrm{H}, \mathrm{d}, J=7.7 \mathrm{~Hz}, \mathrm{H}-\mathrm{o}-\mathrm{Ph}), 8.02(1 \mathrm{H}, \mathrm{td}, J=1.6$ and $7.8 \mathrm{~Hz}, \mathrm{H}-4 \mathrm{~A}), 7.94-7.73$ $\left(12 \mathrm{H}, \mathrm{m}, \mathrm{H}-1^{\prime}, \mathrm{H}-3^{\prime}\right.$ and $\left.\mathrm{H}-m, p-\mathrm{Ph}\right), 7.70-7.66\left(\mathrm{H}-5{ }^{\prime \prime}\right.$ and $\left.\mathrm{H}-m-\mathrm{Ph}\right), 7.57-7.54(1 \mathrm{H}, \mathrm{m}, \mathrm{H}-5 \mathrm{~B})$, 7.48-7.45 (1H, m, H-5A), 7.40-7.36 (1H, m, H-p-Ph), $7.34\left(1 \mathrm{H}, \mathrm{d}, J=8.1 \mathrm{~Hz}, \mathrm{H}-4^{\prime}\right),-2,73$ 
(2H, s, NH) ppm. $\left.{ }^{13} \mathrm{C} \mathrm{NMR} \mathrm{(125} \mathrm{MHz,} \mathrm{CDCl}_{3}\right): \delta 159.8,157.0,156.5,156.0,155.2,152.2$, 151.3, 150.6, 149.7, 147.9, 147.7, 143.0, 141.9, 141.7, 139.2, 138.6, 134.5, 134.4, 134.3, 134.0, 133.6, 133.5, 133.2, 132.3-129.8 (C- $\beta$ ), 129.1, 128.9, 128.4, 128.3, 128.04, 127.97, 127.9, 127.7, $127.2,127.1,127.0,126.9,126.8,126.5,126.4,125.1,124.3,122.5,121.5,118.1,117.5,117.2 \mathrm{ppm}$. MS $(\operatorname{ESI}(+))=1129.3\left[\mathrm{M}^{+}\right.$. V-Vis (DMF): $\lambda_{\max }(\log \varepsilon) 286(4.44), 313(4.43), 323(4.45) 427$ (5.45), 518 (4.01), 593 (3.57) nm. MS-ESI(+): $1129.4[\mathrm{M}+2 \mathrm{H}]^{+}$. HRMS-ESI(+): $\mathrm{m} / \mathrm{z}$ calcd. for $\mathrm{C}_{63} \mathrm{H}_{45} \mathrm{ClN}_{7} \mathrm{Pt} 1129.2916[\mathrm{M}+2 \mathrm{H}]^{+}$; found 1129.2963.

Compound 2b: Yield: $87 \% .{ }^{1} \mathrm{H}$ NMR $\left(500 \mathrm{MHz}, \mathrm{CDCl}_{3}\right): \delta 9.85(1 \mathrm{H}, \mathrm{dd}, J=0.9$ and $5.9 \mathrm{~Hz}, \mathrm{H}-6 \mathrm{~B}), 9.59(1 \mathrm{H}, \mathrm{dd}, J=0.9$ and $5.6 \mathrm{~Hz}, \mathrm{H}-6 \mathrm{~A}), 8.95(1 \mathrm{H}, \mathrm{d}, J=5.0 \mathrm{~Hz}, \mathrm{H}-\beta)$, $8.91(1 \mathrm{H}, \mathrm{d}, J=5.0 \mathrm{~Hz}, \mathrm{H}-\beta), 8.87(1 \mathrm{H}, \mathrm{d}, J=5.0 \mathrm{~Hz}, \mathrm{H}-\beta), 8.80(1 \mathrm{H}, \mathrm{d}, J=4.9 \mathrm{~Hz}, \mathrm{H}-\beta)$, $8.76\left(2 \mathrm{H}, \mathrm{d}, J=6.6 \mathrm{~Hz}, \mathrm{H}-2^{\prime \prime}\right.$ and H-6"), 8.73-8.70 $(2 \mathrm{H}, \mathrm{m}, \mathrm{H}-\beta), 8.42(1 \mathrm{H}, \mathrm{d}, J=8.0 \mathrm{~Hz}$, $\mathrm{H}-o-\mathrm{Ph}), 8.37-8.34$ (2H, m, H-o-Ph), 8.29-8.18 (8H, m, H-4A, H-3B, H-o-Ph), 8.16 (1H, td, $J=1.4$ and $7.9 \mathrm{~Hz}, \mathrm{H}-4 \mathrm{~B}), 7.98-7.95\left(4 \mathrm{H}, \mathrm{m}, \mathrm{H}-3^{\prime}, \mathrm{H}-3^{\prime \prime}, \mathrm{H}^{-5}{ }^{\prime \prime}\right.$ and $\left.\mathrm{H}-3 \mathrm{~A}\right), 7.93-7.74(11 \mathrm{H}, \mathrm{m}$, $\mathrm{H}-m, p-\mathrm{Ph}$ and $\left.\mathrm{H}-1^{\prime}\right), 7.69-7.66(1 \mathrm{H}, \mathrm{m}, \mathrm{H}-5 \mathrm{~B}), 7.64-7.61(2 \mathrm{H}, \mathrm{m}, \mathrm{H}-\mathrm{p}-\mathrm{Ph}$ and $\mathrm{H}-5 \mathrm{~A}), 7.36(1 \mathrm{H}$, $\left.\mathrm{d}, J=8.4 \mathrm{~Hz}, \mathrm{H}-4^{\prime}\right),-2.70(2 \mathrm{H}, \mathrm{s}, \mathrm{NH}) \mathrm{ppm} .{ }^{13} \mathrm{C} \mathrm{NMR}\left(125 \mathrm{MHz}, \mathrm{CDCl}_{3}\right): \delta 159.9,156.8$, 156.1, 155.2, 152.6, 150.8, 150.7, 150.1, 148.0, 147.6, 146.9, 146.0, 143.2, 141.8, 141.7, 141.6, 139.2, 138.3, 135.5, 134.5, 134.4, 134.3, 133.5, 133.0, 132.3-129.63 (C- $\beta$ ), 129.3, 129.14, 129.12, 129.0, 128.5, 128.3, 128.1, 128.0, 127.9, 127.3, 127.2, 126.9, 126.84, 126.79, 124.9, 124.8, 124.1, 123.0, 122.4, 121.6, 121.5, 118.2, 117.9, 117.6 ppm. UV-Vis (DMF): $\lambda_{\max }(\log \varepsilon) 312$ (4.67), 324 (4.43), 427 (5.49), 520 (4.32), 594 (3.87) nm. MS-ESI(+): $1129.3[\mathrm{M}+2 \mathrm{H}]^{+}$. HRMS-ESI(+): $\mathrm{m} / \mathrm{z}$ calcd. for $\mathrm{C}_{63} \mathrm{H}_{45} \mathrm{ClN}_{7} \mathrm{Pt} 1129.2916[\mathrm{M}+2 \mathrm{H}]^{+}$; found 1129.2926 .

\subsubsection{Synthesis of Cationic Benzoporphyrins 3a, $\mathbf{b}$}

The appropriate neutral benzoporphyrin $\mathbf{1 a}, \mathbf{b}(20 \mathrm{mg}, 27 \mu \mathrm{mol})$ was dissolved in DMF $(1.0 \mathrm{~mL})$ and to the solution was added an excess of iodomethane $(0.1 \mu \mathrm{L}, 1.6 \mathrm{mmol})$. The resulting mixture was stirred at $40{ }^{\circ} \mathrm{C}$ for $18 \mathrm{~h}$, and, after this period, diethyl ether was added. The precipitate obtained was filtered through a cotton pad and washed with diethyl ether. Then, the solid was dissolved with a $\mathrm{CH}_{2} \mathrm{Cl}_{2} / \mathrm{MeOH}$ (95:5) mixture, the solvent evaporated, and the expected compounds $\mathbf{3 a}$ and $\mathbf{3 b}$ were obtained in almost quantitative yield, after hexane $/ \mathrm{CH}_{2} \mathrm{Cl}_{2}$ crystallization.

Compound 3a: Yield: $98 \% .{ }^{1} \mathrm{H}$ NMR $\left(300 \mathrm{MHz}, \mathrm{CDCl}_{3}\right): \delta 9.32(1 \mathrm{H}, \mathrm{dd}, J=5.9 \mathrm{~Hz}$, $\left.\mathrm{H}-4^{\prime \prime}\right)$, 8.89-8.79 $(4 \mathrm{H}, \mathrm{m}, \mathrm{H}-\beta), 8.66-8.60\left(3 \mathrm{H}, \mathrm{H}-\beta\right.$ and $\left.\mathrm{H}-2^{\prime \prime}\right), 8.17-8.11(8 \mathrm{H}, \mathrm{m}, \mathrm{H}-\mathrm{o}-\mathrm{Ph})$, 7.98-7.96 (1H, m, H-5"), $7.92\left(2 \mathrm{H}, \mathrm{d}, J=8.4 \mathrm{~Hz}, \mathrm{H}-3^{\prime}\right), 7.88\left(1 \mathrm{H}, \mathrm{d}, J=7.6 \mathrm{~Hz}, \mathrm{H}-6^{\prime \prime}\right), 7.81-7.66$ $\left(13 \mathrm{H}, \mathrm{m}, \mathrm{H}-\mathrm{m}, \mathrm{p}-\mathrm{Ph}\right.$ and $\left.\mathrm{H}-1^{\prime}\right), 7.33\left(1 \mathrm{H}, \mathrm{d}, J=8.4 \mathrm{~Hz}, \mathrm{H}-4^{\prime}\right), 4.66\left(3 \mathrm{H}, \mathrm{s},-\mathrm{CH}_{3}\right)-2.76(2 \mathrm{H}$, $\mathrm{s}, \mathrm{NH}) \mathrm{ppm} .{ }^{13} \mathrm{C} \mathrm{NMR}\left(125 \mathrm{MHz}, \mathrm{CDCl}_{3}\right): \delta 159.7,155.4,146.3,145.8,145.6,144.5,143.6$, $142.8,141.9,141.7,141.6,140.0,138.4,138.3,135.4,134.53,134.49,134.4,133.6,133.5,129.1$, 128.3, 128.2, 128.1, 128.01, 127.98, 127.95, 127.2, 126.9, 121.72, 121.65, 118.3, 117.7, 117.2, 49.6 ppm. UV-Vis (DMF): $\lambda_{\max }$ (log ع) 427 (5.39), 518 (4.07), 593 (3.72) nm. MS-ESI(+): 757.5 $[\mathrm{M}+2 \mathrm{H}]^{+\bullet}$. HRMS-ESI $(+): m / z$ calcd. for $\mathrm{C}_{54} \mathrm{H}_{39} \mathrm{~N}_{5} 757.3122[\mathrm{M}+2 \mathrm{H}]^{+\bullet}$; found 757.3094 .

Compound 3b: Yield: $97 \% .{ }^{1} \mathrm{H}$ NMR $\left(300 \mathrm{MHz}, \mathrm{CDCl}_{3}\right): \delta 8.98-8.92(4 \mathrm{H}, \mathrm{m}, \mathrm{H}-\beta$ and H-3", 5"), $8.85(1 \mathrm{H}, \mathrm{d}, J=5.0 \mathrm{~Hz}, \mathrm{H}-\beta), 8.81(1 \mathrm{H}, \mathrm{d}, J=5.0 \mathrm{~Hz}, \mathrm{H}-\beta), 8.73(2 \mathrm{H}, \mathrm{s}, \mathrm{H}-\beta), 8.39$ $\left(2 \mathrm{H}, \mathrm{d}, J=6.9 \mathrm{~Hz}, \mathrm{H}-2^{\prime \prime}, 6^{\prime \prime}\right), 8.24-8.19(6 \mathrm{H}, \mathrm{m}, \mathrm{H}-o-\mathrm{Ph}), 8.15(2 \mathrm{H}, \mathrm{d}, J=6.8 \mathrm{~Hz}, \mathrm{H}-o-\mathrm{Ph})$, $8.09\left(1 \mathrm{H}, \mathrm{d}, J=8.5 \mathrm{~Hz}, \mathrm{H}-3^{\prime}\right), 8.04-7.93(3 \mathrm{H}, \mathrm{m}, \mathrm{H}-m, p-\mathrm{Ph}), 7.88-7.72(10 \mathrm{H}, \mathrm{m}, \mathrm{H}-m, p-\mathrm{Ph}$ and $\left.\mathrm{H}_{-1} \mathrm{1}^{\prime}\right), 7.37\left(1 \mathrm{H}, \mathrm{d}, J=8.5 \mathrm{~Hz}, \mathrm{H}-4^{\prime}\right), 4.67\left(3 \mathrm{H}, \mathrm{s},-\mathrm{CH}_{3}\right),-2.64(2 \mathrm{H}, \mathrm{s}, \mathrm{NH}) \mathrm{ppm} .{ }^{13} \mathrm{C}$ $\operatorname{NMR}\left(125 \mathrm{MHz} \mathrm{CDCl}_{3}\right) \delta 159.9,155.5,155.4,155.0,147.1,146.5,145.7,145.5,144.8,143.1$, $141.64,141.60,141.57,140.0,138.8,138.5,136.1,134.5,134.3,133.4,133.2,129.2,128.6,128.4$, $128.2,128.1,128.0,127.6,127.3,126.90,126.87,126.6,125.2,121.8,121.6,119.1,118.5,117.6$, $49.1 \mathrm{ppm}$. UV-Vis (DMF): $\lambda_{\max }(\log \varepsilon) 429$ (5.06), 522 (4.15), 597(3.74) nm. MS ESI(+): 757.3 $[\mathrm{M}+2 \mathrm{H}]^{+\bullet}$. HRMS-ESI $(+): m / z$ calcd. for $\mathrm{C}_{54} \mathrm{H}_{39} \mathrm{~N}_{5} 757.3122[\mathrm{M}+2 \mathrm{H}]^{+\bullet}$; found 757.3129 .

\subsection{General Procedure to Prepare PVP-PS Micelles}

Chloroform solutions of $N$-vinylpyrrolidone (100 mg) and compounds $\mathbf{2} \mathbf{a}, \mathbf{b}$ or $\mathbf{3 a}, \mathbf{b}$ $(10 \% w / w)$ were mixed in a Becker and the solution stirred for $2 \mathrm{~h}$ at room temperature for a full homogenization. Then, the solvent was evaporated under nitrogen flow and the 
reddish-brown solid obtained was dried in an oven at $40{ }^{\circ} \mathrm{C}$ for $48 \mathrm{~h}$. The resulting residues were dissolved in $2 \mathrm{~mL}$ of water and submitted to dialysis in distilled water at $\mathrm{pH} 7$. After this approach, PVP-2a,b and PVP-3a,b formulations were obtained.

\subsection{Photostability Assays}

In a glass cuvette, we prepared PBS solutions of PVP-based formulations PVP-2a, $\mathbf{b}$ and PVP-3a,b $(5.0 \mu \mathrm{M})$, which were kept in the dark at room temperature. Then, the solutions were irradiated with white light $(400-750 \mathrm{~nm})$ using a light emission diode (LED) system (ELMARK-VEGA20, $20 \mathrm{~W}, 1400 \mathrm{~lm}$ ) with an irradiance of $25 \mathrm{~mW} \cdot \mathrm{cm}^{-2}$, for $30 \mathrm{~min}$. The absorption spectra were recorded at $0,1,2,3,4,5,10,20$, and 30 min after irradiation.

\subsection{Singlet Oxygen Generation}

To evaluate the ability of PVP formulations (PVP-2a, b, and PVP-3a, $\mathbf{b}$ ) to generate singlet oxygen $\left({ }^{1} \mathrm{O}_{2}\right)$, in a $1 \times 1 \mathrm{~cm}$ cuvette, we prepared $3 \mathrm{~mL}$ solutions, each one containing a PS $(0.5 \mu \mathrm{M})$ and DPiBF $(50 \mu \mathrm{M})$ in DMF. The solutions were irradiated with a red-light LED board $(630 \pm 20 \mathrm{~nm})$ at an irradiance of $11 \mathrm{~mW} \cdot \mathrm{cm}^{-2}$ for $15 \mathrm{~min}$ at room temperature under gentle magnetic stirring. Control assays using a DPiBF solution at $50 \mu \mathrm{M}$ and the PVP and PVP-TPP formulations $(0.5 \mu \mathrm{M})$ and just a DPiBF $(50 \mu \mathrm{M})$ were also performed.

\subsection{Photodynamic Activity of PVP-2a,b and PVP-3a,b Formulations against Human Bladder Cancer Cells}

The study of the PDT efficiency of PVP-2a, $\mathbf{b}$ and PVP-3a,b formulations was conducted using a human bladder cancer cell line HT-1376 derived from high-grade transitional cell carcinoma (from the American Type Culture Collection, ATCC, Manassas, VA, USA). This cell line was cultured in Roswell Park Memorial Institute medium (RPMI-1640) supplemented with $10 \%(v / v)$ of fetal bovine serum (Life Technologies, Carlsbad, CA, USA), $100 \mathrm{U} / \mathrm{mL}$ penicillin, $100 \mathrm{mg} / \mathrm{mL}$ streptomycin and $0.25 \mathrm{mg} / \mathrm{mL}$ amphotericin $\mathrm{B}$ (Sigma, Darmstadt, Germany).

\subsubsection{Cellular Uptake of PVP-2a,b and PVP-3a,b Formulations}

For the determination of the cellular uptake of PVP-2a,b and PVP-3a,b formulations, HT-1376 cells were seeded $\left(9.4 \times 10^{4}\right.$ cells.cm $\left.{ }^{-2}\right)$ in 96-well cell culture plates and maintained in culture medium under an air atmosphere containing $5 \%$ of $\mathrm{CO}_{2}$. After seeding the cells overnight, they were washed twice with PBS and incubated for $2 \mathrm{~h}$ and $4 \mathrm{~h}$ in darkness (at $37^{\circ} \mathrm{C}$ under air atmosphere containing $5 \%$ of $\mathrm{CO}_{2}$ ) with PVP-2a,b and PVP-3a,b at 2.5, $5.0,10.0$, and $12.5 \mu \mathrm{M}$ concentrations. HT-1376 cells were immediately washed with PBS and lysed in $1 \% \mathrm{~m} / v$ sodium dodecyl sulfate (SDS; Sigma) in PBS. PVP-2a,b and PVP-3a,b intracellular concentration was determined by spectrofluorimetry using a microplate reader Synergy HT, BioTek, Winooski, VT, USA, equipped with excitation/emission wavelengths set at $360 \mathrm{~nm} / 675 \mathrm{~nm}$. The results were normalized for protein concentration (determined by bicinchoninic acid reagent; Pierce, Rockford, IL, USA).

\subsubsection{Cell Viability after PDT Treatment with PVP-2a,b and PVP-3a,b Formulations}

HT-1376 cells were seeded $\left(9.4 \times 10^{4}\right.$ cells.cm $\left.{ }^{-2}\right)$ in 96 -well cell culture plates and maintained in culture medium under an air atmosphere containing $5 \%$ of $\mathrm{CO}_{2}$ overnight. The cells were washed twice with PBS and incubated with 2.5, 5.0,10.0, and $12.5 \mu \mathrm{M}$ of PVP-2,ab and PVP-3a,b formulations for $4 \mathrm{~h}$ in the dark. The cells were then washed twice with PBS and covered with $100 \mu \mathrm{L}$ of fresh medium. The cells were irradiated for $40 \mathrm{~min}$ with white light delivered by an illumination system (LC-122 LumaCare, London, UK) equipped with a halogen/quartz $250 \mathrm{~W}$ lamp coupled to the selected interchangeable optic fiber probe $(400-800 \mathrm{~nm})$ at a fluence rate of $20 \mathrm{~mW} \cdot \mathrm{cm}^{-2}$. After irradiation, the cells were incubated in a humidified incubator with $5 \%$ of $\mathrm{CO}_{2}$ atmosphere and $95 \%$ of air. After $24 \mathrm{~h}$ of the PDT protocol, cell phototoxicity was determined by measuring the ability of cancer cells to reduce 3-[4,5-dimethylthiazol-2-yl]-2,5-diphenyl-tetrazolium bromide (MTT, 
Sigma), to a colored formazan using a microplate reader (Synergy HT, Biotek, Winooski, VT, USA). The data were expressed in percentage of control (i.e., optical density of formazan from cells not exposed to PVP formulations).

The dark toxicity of PVP-2,ab and PVP-3a, $\mathbf{b}$ formulations was evaluated under the same protocol, though without the irradiation procedure.

\subsubsection{Statistical Analysis}

The results are presented as mean of at least 3 independent assays with 3 replicates per assay. The statistical analysis was performed with GraphPad Prism (GraphPad Software, San Diego, CA, USA). Statistical significance among the conditions was assessed using the nonparametric Mann-Whitney test.

\section{Conclusions}

In summary, two different approaches to prepare mono-charged benzoporphyrinbased Ps were efficiently developed. The reaction of the neutral precursors with $\left(2,2^{\prime}\right.$ bipyridine)dichloroplatinum(II) allows preparing the corresponding benzoporphyrinplatinum(II) modified at the isoindole-type unit in good-to-excellent yields, while the alkylation with iodomethane gives the cationic benzoporphyrins in almost quantitative yields. All the mono-cationic benzoporphyrin derivatives prepared were successfully incorporated in PVP micelles, allowing to improve their solubility in aqueous medium.

Both compounds and PVP-PSs formulations display photophysical features typical of free-base porphyrin derivatives, which are not noticeably affected by the different moieties inserted into the benzoporphyrin core. The PVP-PSs formulations prepared are stable when irradiated with white light and all are able to generate singlet oxygen. However, the PVP formulations prepared with the benzoporphyrin-platinum(II) derivatives exhibit better performance in the ${ }^{1} \mathrm{O}_{2}$ generation.

Under the context of PDT evaluation, PVP-3a,b formulations demonstrated higher photostability, higher internalization into the cancer cell line, and, consequently, were the most active PSs causing a decrease in HT-1376 cell viability higher than the corresponding formulations with benzoporphyrin-platinum(II) derivatives. Moreover, the synthetic approach to prepare the mono-cationic derivatives $\mathbf{3} \mathbf{a}, \mathbf{b}$ exhibits a much better cost-effectiveness relationship when compared with the route to prepare the corresponding derivatives $\mathbf{2 a}, \mathbf{b}$, due to affording almost quantitative yields for both compounds, as well as the high cost associated with (2,2'-bipyridine)chloroplatinum(II) or its synthesis.

Additionally, none of the formulations tested exhibit dark toxicity for HT-1376 cell line, suggesting that the phototoxic effect is due to the reactive oxygen species production under irradiation. These promising results encourage further in vitro and in vivo test studies of benzoporphyrin derivatives as prototypes of future PDT agents.

Supplementary Materials: The following are available online, Figures S1-S22: copies of ${ }^{1} \mathrm{H},{ }^{13} \mathrm{C}, 2 \mathrm{D}$ NMR, and MS spectra of compounds $\mathbf{2} \mathbf{a}, \mathbf{b}$ and $\mathbf{3} \mathbf{a}, \mathbf{b}$; Figure S23: UV-Vis, emission, and excitation spectra of compounds $\mathbf{2} \mathbf{a}$ and $\mathbf{3 b}$, and PVP formulations PVP-2b and PVP-3b; Figure S24: Dark toxicity of formulations PVP-2a,b and PVP-3a,b in HT-1376 cells; Table S1: photostability data of PVP formulations.

Author Contributions: Investigation-N.M.M.M. (Synthesis, structural and photophysical characterization), A.T.P.C.G. (Incorporation into PVP micelles and biological evaluation), ValidationM.G.P.M.S.N., R.F. and J.A.S.C.; Supervision-M.G.P.M.S.N. and R.F.; Formal analysis-C.F.R.; Writing-original draft-N.M.M.M. and A.T.P.C.G.; Writing-review and editing-N.M.M.M., A.T.P.C.G., M.G.P.M.S.N., R.F. and J.A.S.C. All authors have read and agreed to the published version of the manuscript.

Funding: Thanks are due to the University of Aveiro and FCT/MCT for the financial support for the LAQV-REQUIMTE (UIDB/50006/2020), CIBB (UIDB/04539/2020, UIDP/04539/2020), and CNC.IBILI (UID/NEU/04539/2019) research units through national funds within the PT2020 Partnership Agreement, and to the Portuguese NMR Network. NMM Moura thanks his research contract 
(CDL-CTTRI-048-88-ARH/2018), which is funded by national funds (OE), through FCT-Fundação para a Ciência e a Tecnologia, I.P., in the scope of the framework contract foreseen in numbers 4, 5, and 6 of the article 23 of the Law Decree 57/2016 of 29August, changed by Law 57/2017 of 19 July.

Institutional Review Board Statement: Not applicable.

Informed Consent Statement: Not applicable.

Data Availability Statement: The data presented in this study are available in the Supplementary Materials.

Conflicts of Interest: The authors declare no conflict of interest.

Sample Availability: Samples of compounds 1-3 are available from the authors.

\section{References}

1. Sung, H.; Ferlay, J.; Siegel, R.L.; Laversanne, M.; Soerjomataram, I.; Jemal, A.; Bray, F. Global Cancer Statistics 2020: GLOBOCAN Estimates of Incidence and Mortality Worldwide for 36 Cancers in 185 Countries. CA Cancer J. Clin. 2021, 71, 209-249. [CrossRef]

2. Liu, H.; Lu, C.; Han, L.; Zhang, X.; Song, G. Optical-Magnetic probe for evaluating cancer therapy. Coord. Chem. Rev. 2021, 441, 213978. [CrossRef]

3. Hang, Z.; Cooper, M.A.; Ziora, Z.M. Platinum-based anticancer drugs encapsulated liposome and polymeric micelle formulation in clinical trials. Biochem. Compd. 2016, 4, 2. [CrossRef]

4. Tuo, W.; Xu, Y.; Fan, Y.; Li, J.; Qiu, M.; Xiong, X.; Li, X.; Sun, Y. Biomedical applications of Pt(II) metallacycle/metallacage-based agents: From mono-chemotherapy to versatile imaging contrasts and theranostic platforms. Coord. Chem. Rev. 2021, $443,214017$. [CrossRef]

5. Gabano, E.; Ravera, M.; Osella, D. Pros and cons of bifunctional platinum(iv) antitumor prodrugs: Two are (not always) better than one. Dalton Trans. 2014, 43, 9813-9820. [CrossRef] [PubMed]

6. Ndagi, U.; Mhlongo, N.; Soliman, M.E. Metal complexes in cancer therapy—An update from drug design perspective. Drug Des. Dev. Ther. 2017, 11, 599-616. [CrossRef]

7. Cocetta, V.; Ragazzi, E.; Montopoli, M. Mitochondrial Involvement in Cisplatin Resistance. Int. J. Mol. Sci. 2019, $20,3384$. [CrossRef]

8. Facchetti, G.; Rimoldi, I. Anticancer platinum(II) complexes bearing N-heterocycle rings. Bioorgan. Med. Chem. Lett. 2019, 29, 1257-1263. [CrossRef] [PubMed]

9. Dai, Z.; Wang, Z. Photoactivatable Platinum-Based Anticancer Drugs: Mode of Photoactivation and Mechanism of Action. Molecules 2020, 25, 5167. [CrossRef]

10. Köberle, B.; Schoch, S. Platinum Complexes in Colorectal Cancer and Other Solid Tumors. Cancers 2021, 13, 2073. [CrossRef]

11. Martinho, N.; Santos, T.C.B.; Florindo, H.F.; Silva, L.C. Cisplatin-Membrane Interactions and Their Influence on Platinum Complexes Activity and Toxicity. Front. Physiol. 2019, 9, 1898. [CrossRef]

12. Wang, Z.; Deng, Z.; Zhu, G. Emerging platinum(iv) prodrugs to combat cisplatin resistance: From isolated cancer cells to tumor microenvironment. Dalton Trans. 2019, 48, 2536-2544. [CrossRef]

13. Nayeem, N.; Contel, M. Exploring the Potential of Metallodrugs as Chemotherapeutics for Triple Negative Breast Cancer. Chem. Eur. J. 2021, 27, 8891-8917. [CrossRef]

14. Li, J.; Chen, T. Transition metal complexes as photosensitizers for integrated cancer theranostic applications. Coord. Chem. Rev. 2020, 418, 213355. [CrossRef]

15. Zhang, Q.; He, J.; Yu, W.; Li, Y.; Liu, Z.; Zhou, B.; Liu, Y. A promising anticancer drug: A photosensitizer based on the porphyrin skeleton. RSC Med. Chem. 2020, 11, 427-437. [CrossRef] [PubMed]

16. Kwon, N.; Kim, H.; Li, X.; Yoon, J. Supramolecular agents for combination of photodynamic therapy and other treatments. Chem. Sci. 2021, 12, 7248-7268. [CrossRef]

17. Huang, L.; Zhao, S.; Wu, J.; Yu, L.; Singh, N.; Yang, K.; Lan, M.; Wang, P.; Kim, J.S. Photodynamic therapy for hypoxic tumors: Advances and perspectives. Coord. Chem. Rev. 2021, 438, 213888. [CrossRef]

18. Chen, D.; Xu, Q.; Wang, W.; Shao, J.; Huang, W.; Dong, X. Type I Photosensitizers Revitalizing Photodynamic Oncotherapy. Small 2021, 17, 2006742. [CrossRef] [PubMed]

19. Yang, B.; Chen, Y.; Shi, J. Reactive Oxygen Species (ROS)-Based Nanomedicine. Chem. Rev. 2019, 119, 4881-4985. [CrossRef] [PubMed]

20. Gomes, A.T.P.D.C.; Neves, M.G.P.M.S.; Cavaleiro, J.A. Cancer, Photodynamic Therapy and Porphyrin-Type Derivatives. An. Acad. Bras. Cienc. 2018, 90, 993-1026. [CrossRef] [PubMed]

21. Hamblin, M.R. Antimicrobial photodynamic inactivation: A bright new technique to kill resistant microbes. Curr. Opin. Microbiol. 2016, 33, 67-73. [CrossRef]

22. Dąbrowski, J.M.; Pucelik, B.; Regiel-Futyra, A.; Brindell, M.; Mazuryk, O.; Kyzioł, A.; Stochel, G.; Macyk, W.; Arnaut, L. Engineering of relevant photodynamic processes through structural modifications of metallotetrapyrrolic photosensitizers. Coord. Chem. Rev. 2016, 325, 67-101. [CrossRef] 
23. Dharmaratne, P.; Sapugahawatte, D.N.; Wang, B.; Chan, C.L.; Lau, K.-M.; Lau, C.B.; Fung, K.P.; Ng, D.K.; Ip, M. Contemporary approaches and future perspectives of antibacterial photodynamic therapy (aPDT) against methicillin-resistant Staphylococcus aureus (MRSA): A systematic review. Eur. J. Med. Chem. 2020, 200, 112341. [CrossRef]

24. Han, Q.; Lau, J.W.; Do, T.C.; Zhang, Z.; Xing, B. Near-infrared light brightens bacterial disinfection: Recent progress and perspectives. ACS Appl. Bio Mater. 2020, 4, 3937-3961. [CrossRef]

25. Vallejo, M.; Moura, N.M.M.; Gomes, A.; Joaquinito, A.; Faustino, M.A.F.; Almeida, A.; Gonçalves, I.; Serra, V.V.; Neves, M.G.P.M.S. The Role of Porphyrinoid Photosensitizers for Skin Wound Healing. Int. J. Mol. Sci. 2021, 22, 4121. [CrossRef] [PubMed]

26. Braz, M.; Salvador, D.; Gomes, A.T.; Mesquita, M.Q.; Faustino, M.A.F.; Neves, M.G.P.M.; Almeida, A. Photodynamic inactivation of methicillin-resistant Staphylococcus aureus on skin using a porphyrinic formulation. Photodiagn. Photodyn. Ther. 2020, 30 101754. [CrossRef] [PubMed]

27. Mesquita, M.Q.; Dias, C.J.; Neves, M.G.P.M.S.; Almeida, A.; Faustino, M.A.F. Revisiting Current Photoactive Materials for Antimicrobial Photodynamic Therapy. Molecules 2018, 23, 2424. [CrossRef]

28. Vieira, C.; Santos, A.; Mesquita, M.Q.; Gomes, A.T.P.D.C.; Neves, M.G.P.M.S.; Faustino, M.A.F.; Almeida, A. Advances in aPDT based on the combination of a porphyrinic formulation with potassium iodide: Effectiveness on bacteria and fungi planktonic/biofilm forms and viruses. J. Porphyr. Phthalocyanines 2019, 23, 534-545. [CrossRef]

29. Almeida, A.; Faustino, M.A.F.; Tome, J.P.C. Photodynamic inactivation of bacteria: Finding the effective targets. Future Med. Chem. 2015, 7, 1221-1224. [CrossRef] [PubMed]

30. Kadish, K.M.; Smith, K.M.; Guilard, R. Handbook of Porphyrin Science; World Scientific Publishing Company: Singapore, 2010.

31. Lee, H.; Hong, K.-I.; Jang, W.-D. Design and applications of molecular probes containing porphyrin derivatives. Coord. Chem. Rev. 2018, 354, 46-73. [CrossRef]

32. Paolesse, R.; Nardis, S.; Monti, D.; Stefanelli, M.; Di Natale, C. Porphyrinoids for Chemical Sensor Applications. Chem. Rev. 2016, 117, 2517-2583. [CrossRef]

33. Ding, Y.; Zhu, W.-H.; Xie, Y. Development of Ion Chemosensors Based on Porphyrin Analogues. Chem. Rev. 2016, 117, 2203-2256. [CrossRef]

34. Moura, N.M.M.; Núñez, C.; Santos, S.M.; Faustino, M.A.F.; Cavaleiro, J.A.S.; Paz, F.A.; Neves, M.G.P.M.S.; Capelo, J.L.; Lodeiro, C. A New 3,5-Bisporphyrinylpyridine Derivative as a Fluorescent Ratiometric Probe for Zinc Ions. Chem. Eur. J. 2014, 20, 6684-6692. [CrossRef]

35. Moura, N.M.M.; Núñez, C.; Santos, S.M.; Faustino, M.A.F.; Cavaleiro, J.A.S.; Neves, M.G.P.M.S.; Capelo, J.L.; Lodeiro, C. Synthesis, Spectroscopy Studies, and Theoretical Calculations of New Fluorescent Probes Based on Pyrazole Containing Porphyrins for Zn(II), Cd(II), and Hg(II) Optical Detection. Inorg. Chem. 2014, 53, 6149-6158. [CrossRef]

36. Neves, C.; Filipe, O.M.; Mota, N.; Santos, S.; Silvestre, A.J.; Santos, E.; Neves, M.G.P.M.; Simões, M.M. Photodegradation of metoprolol using a porphyrin as photosensitizer under homogeneous and heterogeneous conditions. J. Hazard. Mater. 2018, 370, 13-23. [CrossRef] [PubMed]

37. Pegis, M.L.; Wise, C.F.; Martin, D.; Mayer, J.M. Oxygen Reduction by Homogeneous Molecular Catalysts and Electrocatalysts. Chem. Rev. 2017, 118, 2340-2391. [CrossRef]

38. Da Silva, E.S.; Moura, N.M.M.; Neves, M.G.P.M.S.; Coutinho, A.; Prieto, M.; Silva, C.G.; Faria, J. Novel hybrids of graphitic carbon nitride sensitized with free-base meso-tetrakis(carboxyphenyl) porphyrins for efficient visible light photocatalytic hydrogen production. Appl. Catal. B Environ. 2018, 221, 56-69. [CrossRef]

39. Zhang, W.; Lai, W.; Cao, R. Energy-Related Small Molecule Activation Reactions: Oxygen Reduction and Hydrogen and Oxygen Evolution Reactions Catalyzed by Porphyrin- and Corrole-Based Systems. Chem. Rev. 2016, 117, 3717-3797. [CrossRef]

40. Nakagaki, S.; Mantovani, K.M.; Machado, G.S.; Castro, K.A.D.D.F.; Wypych, F. Recent Advances in Solid Catalysts Obtained by Metalloporphyrins Immobilization on Layered Anionic Exchangers: A Short Review and Some New Catalytic Results. Molecules 2016, 21, 291. [CrossRef]

41. Costentin, C.; Robert, M.; Savéant, J.-M. Current Issues in Molecular Catalysis Illustrated by Iron Porphyrins as Catalysts of the CO2-to-CO Electrochemical Conversion. Acc. Chem. Res. 2015, 48, 2996-3006. [CrossRef] [PubMed]

42. Chen, Y.; Jiang, D.; Gong, Z.; Li, Q.; Shi, R.; Yang, Z.; Lei, Z.; Li, J.; Wang, L.-N. Visible-light responsive organic nanoheterostructured photocatalysts for environmental remediation and H2 generation. J. Mater. Sci. Technol. 2019, 38, 93-106. [CrossRef]

43. Radi, S.; El Abiad, C.; Moura, N.M.; Faustino, M.A.; Neves, M.G.P. New hybrid adsorbent based on porphyrin functionalized silica for heavy metals removal: Synthesis, characterization, isotherms, kinetics and thermodynamics studies. J. Hazard. Mater. 2019, 370, 80-90. [CrossRef]

44. El Abiad, C.; Radi, S.; Faustino, M.A.F.; Neves, M.G.P.M.S.; Moura, N.M.M. Supramolecular Hybrid Material Based on Engineering Porphyrin Hosts for an Efficient Elimination of Lead(II) from Aquatic Medium. Molecules 2019, 24, 669. [CrossRef]

45. DI Carlo, G.; Biroli, A.O.; Pizzotti, M.; Tessore, F. Efficient Sunlight Harvesting by A4 $\beta$-Pyrrolic Substituted ZnII Porphyrins: A Mini-Review. Front. Chem. 2019, 7, 177. [CrossRef]

46. DI Carlo, G.; Biroli, A.O.; Tessore, F.; Caramori, S.; Pizzotti, M. $\beta$-Substituted ZnII porphyrins as dyes for DSSC: A possible approach to photovoltaic windows. Coord. Chem. Rev. 2018, 358, 153-177. [CrossRef]

47. Kundu, S.; Patra, A. Nanoscale Strategies for Light Harvesting. Chem. Rev. 2016, 117, 712-757. [CrossRef] [PubMed] 
48. Urbani, M.; Grätzel, M.; Nazeeruddin, M.K.; Torres, T. Meso-Substituted Porphyrins for Dye-Sensitized Solar Cells. Chem. Rev. 2014, 114, 12330-12396. [CrossRef] [PubMed]

49. Almeida-Marrero, V.; González-Delgado, J.A.; Torres, T. Emerging Perspectives on Applications of Porphyrinoids for Photodynamic Therapy and Photoinactivation of Microorganisms. Macroheterocycles 2019, 12, 8-16. [CrossRef]

50. McKenzie, L.K.; Bryant, H.E.; Weinstein, J.A. Transition metal complexes as photosensitisers in one- and two-photon photodynamic therapy. Coord. Chem. Rev. 2019, 379, 2-29. [CrossRef]

51. Sandland, J.; Malatesti, N.; Boyle, R. Porphyrins and related macrocycles: Combining photosensitization with radio- or opticalimaging for next generation theranostic agents. Photodiagn. Photodyn. Ther. 2018, 23, 281-294. [CrossRef] [PubMed]

52. Calvete, M.; Pinto, S.; Pereira, M.M.; Geraldes, C. Metal coordinated pyrrole-based macrocycles as contrast agents for magnetic resonance imaging technologies: Synthesis and applications. Coord. Chem. Rev. 2017, 333, 82-107. [CrossRef]

53. Chang, K.P.; the New Light Group; Kolli, B.K. New "light" for one-world approach toward safe and effective control of animal diseases and insect vectors from leishmaniac perspectives. Parasites Vectors 2016, 9, 396. [CrossRef] [PubMed]

54. Vieira, C.; Gomes, A.T.P.D.C.; Mesquita, M.Q.; Moura, N.M.M.; Neves, M.G.P.M.S.; Faustino, M.A.F.; Almeida, A. An Insight into the Potentiation Effect of Potassium Iodide on aPDT Efficacy. Front. Microbiol. 2018, 9, 2665. [CrossRef]

55. Lin, Y.; Zhou, T.; Bai, R.; Xie, Y. Chemical approaches for the enhancement of porphyrin skeleton-based photodynamic therapy. J. Enzym. Inhib. Med. Chem. 2020, 35, 1080-1099. [CrossRef] [PubMed]

56. Chelushkin, P.S.; Tunik, S.P. Phosphorescence Lifetime Imaging (PLIM): State of the Art and Perspectives. In Progress in Photon Science; Springer: Berlin/Heidelberg, Germany, 2019; pp. 109-128.

57. Paul-Roth, C.O.; Drouet, S.; Merhi, A.; Williams, J.; Gildea, L.F.; Pearson, C.; Petty, M. Synthesis of platinum complexes of fluorenyl-substituted porphyrins used as phosphorescent dyes for solution-processed organic light-emitting devices. Tetrahedron 2013, 69, 9625-9632. [CrossRef]

58. Lvova, L.; Verrelli, G.; Stefanelli, M.; Nardis, S.; Di Natale, C.; Amico, A.D.; Makarychev-Mikhailov, S.; Paolesse, R. Platinum porphyrins as ionophores in polymeric membrane electrodes. Analyst 2011, 136, 4966-4976. [CrossRef]

59. Luciano, M.; Br ckner, C. Modifications of porphyrins and hydroporphyrins for their solubilization in aqueous media. Molecules 2017, 22, 980. [CrossRef]

60. Pushpanandan, P.; Maurya, Y.K.; Omagari, T.; Hirosawa, R.; Ishida, M.; Mori, S.; Yasutake, Y.; Fukatsu, S.; Mack, J.; Nyokong, T.; et al. Singly and Doubly N-Confused Calix[4]phyrin Organoplatinum(II) Complexes as Near-IR Triplet Sensitizers. Inorg. Chem. 2017, 56, 12572-12580. [CrossRef]

61. Moura, N.M.M.; Cuerva, C.; Cavaleiro, J.; Mendes, R.F.; Paz, F.A.; Cano, M.; Neves, M.G.P.M.S.; Lodeiro, C. Metallomesogens with Luminescent Behaviour: Palladium Complexes Derived from Alkylamide Tetraarylporphyrins. ChemPlusChem 2016, 81, 262-273. [CrossRef]

62. Ito, S.; Makihata, D.; Ishii, Y.; Saito, Y.; Oba, T. Synthesis of $\pi$-extended platinum porphyrins. Tetrahedron Lett. 2015, 56, 7043-7045. [CrossRef]

63. Chen, H.-C.; Hetterscheid, D.G.H.; Williams, R.M.; Van Der Vlugt, J.I.; Reek, J.N.H.; Brouwer, A.M. Platinum(ii)-porphyrin as a sensitizer for visible-light driven water oxidation in neutral phosphate buffer. Energy Environ. Sci. 2015, 8, 975-982. [CrossRef]

64. Ishihara, S.; Labuta, J.; Van Rossom, W.; Ishikawa, D.; Minami, K.; Hill, J.; Ariga, K. Porphyrin-based sensor nanoarchitectonics in diverse physical detection modes. Phys. Chem. Chem. Phys. 2014, 16, 9713-9746. [CrossRef] [PubMed]

65. Moiseev, A.G.; Margulies, E.A.; Schneider, J.A.; Bélanger-Gariépy, F.; Perepichka, D.F. Protecting the triplet excited state in sterically congested platinum porphyrin. Dalton Trans. 2014, 43, 2676-2683. [CrossRef]

66. Hasegawa, M.; Kurahashi, T.; Matsubara, S. Dicationic platinum porphyrin catalyzed cycloisomerization of enynes. Tetrahedron Lett. 2013, 54, 6196-6198. [CrossRef]

67. Onitsuka, K.; Kitajima, H.; Fujimoto, M.; Iuchi, A.; Takei, F.; Takahashi, S. Platinum-acetylide dendrimers possessing a porphyrin core. Chem. Commun. 2002, 21, 2576-2577. [CrossRef]

68. Xu, X.-D.; Zhang, J.; Chen, L.-J.; Guo, R.; Wang, D.-X.; Yang, H.-B. Design and synthesis of branched platinum-acetylide complexes possessing a porphyrin core and their self-assembly behaviour. Chem. Commun. 2012, 48, 11223-11225. [CrossRef]

69. Jana, A.; McKenzie, L.; Wragg, A.B.; Ishida, M.; Hill, J.P.; Weinstein, J.A.; Baggaley, E.; Ward, M.D. Porphyrin/Platinum(II) C`N^N Acetylide Complexes: Synthesis, Photophysical Properties, and Singlet Oxygen Generation. Chem. Eur. J. 2016, 22, 4164-4174. [CrossRef]

70. Couto, G.K.; Pacheco, B.S.; Borba, V.M.; Junior, J.C.R.; Oliveira, T.L.; Segatto, N.V.; Seixas, F.K.; Acunha, T.V.; Iglesias, B.A.; Collares, T. Tetra-cationic platinum(II) porphyrins like a candidate photosensitizers to bind, selective and drug delivery for metastatic melanoma. J. Photochem. Photobiol. B Biol. 2019, 202, 111725. [CrossRef]

71. Rubbiani, R.; Wu, W.; Naik, A.; Larocca, M.; Schneider, L.; Padrutt, R.; Babu, V.; König, C.; Hinger, D.; Maake, C.; et al. Studying the cellular distribution of highly phototoxic platinated metalloporphyrins using isotope labelling. Chem. Commun. 2020, 56, 14373-14376. [CrossRef]

72. Naik, A.; Rubbiani, R.; Gasser, G.; Spingler, B. Visible-Light-Induced Annihilation of Tumor Cells with Platinum-Porphyrin Conjugates. Angew. Chem. 2014, 126, 7058-7061. [CrossRef]

73. Tasso, T.T.; Tsubone, T.M.; Baptista, M.S.; Mattiazzi, L.M.; Acunha, T.V.; Iglesias, B.A. Isomeric effect on the properties of tetraplatinated porphyrins showing optimized phototoxicity for photodynamic therapy. Dalton Trans. 2017, 46, 11037-11045. [CrossRef] [PubMed] 
74. Alemayehu, A.B.; Vazquez-Lima, H.; Beavers, C.M.; Gagnon, K.J.; Bendix, J.; Ghosh, A. Platinum corroles. Chem. Commun. 2014, 50, 11093-11096. [CrossRef]

75. Iglesias, B.A.; Barata, J.F.; Pereira, P.M.; Girão, H.; Fernandes, R.; Tome, J.; Neves, M.G.P.M.S.; Cavaleiro, J.A. New platinum(II)bipyridyl corrole complexes: Synthesis, characterization and binding studies with DNA and HSA. J. Inorg. Biochem. 2015, 153, 32-41. [CrossRef]

76. Volov, A.N.; Volov, N.A.; Burtsev, I.D. New amphiphilic platinum(II) phthalocyanine with peracetylated $\beta$-galactose moietysynthesis and photophysical properties. Polyhedron 2021, 206, 115331. [CrossRef]

77. Volov, A.N.; Burtsev, I.D. New glycosylated platinum(II) phthalocyanine containing ribose moiety-synthesis and photophysical properties. J. Organomet. Chem. 2020, 922, 121372. [CrossRef]

78. Che, Y.; Yang, W.; Tang, G.; Dumoulin, F.; Zhao, J.; Liu, L.; Isci, U. Photophysical properties of palladium/platinum tetrasulfonyl phthalocyanines and their application in triplet-triplet annihilation upconversion. J. Mater. Chem. C 2018, 6, 5785-5793. [CrossRef]

79. Zorlu, Y.; Dumoulin, F.; Durmuş, M.; Ahsen, V. Comparative studies of photophysical and photochemical properties of solketal substituted platinum(II) and zinc(II) phthalocyanine sets. Tetrahedron 2010, 66, 3248-3258. [CrossRef]

80. Lokesh, K.; Uma, N.; Achar, B. The Microwave-assisted syntheses and a conductivity study of a platinum phthalocyanine and its derivatives. Polyhedron 2009, 28, 1022-1028. [CrossRef]

81. Vallejo, M.C.; Reis, M.J.; Pereira, A.M.; Serra, V.V.; Cavaleiro, J.A.S.; Moura, N.M.M.; Neves, M.G.P.M.S. Merging pyridine(s) with porphyrins and analogues: An overview of synthetic approaches. Dye. Pigment. 2021, 191, 109298. [CrossRef]

82. Yamaguchi, S.; Katoh, T.; Shinokubo, H.; Osuka, A. Pt(II)- and Pt(IV)-Bridged Cofacial Diporphyrins via Carbon-Transition Metal $\sigma$-Bonds. J. Am. Chem. Soc. 2008, 130, 14440-14441. [CrossRef]

83. Yamaguchi, S.; Shinokubo, H.; Osuka, A. Double Cleavage of sp2 C-H and sp3 C-H Bonds on One Metal Center: DMFAppended Cyclometalated Platinum(II) and -(IV) Porphyrins. Inorg. Chem. 2009, 48, 795-797. [CrossRef]

84. Yoshida, K.; Yamaguchi, S.; Osuka, A.; Shinokubo, H. Platinum(II) and Platinum(IV) Porphyrin Pincer Complexes: Synthesis, Structures, and Reactivity. Organometallics 2010, 29, 3997-4000. [CrossRef]

85. Jiang, H.-W.; Tanaka, T.; Osuka, A. Singly and doubly $\beta$-to- $\beta$ platinum-bridged porphyrin dimers and their reductive eliminations. Chem. Sci. 2015, 6, 6102-6105. [CrossRef]

86. Lenis, A.T.; Lec, P.M.; Chamie, K.; MSHS. Bladder Cancer. JAMA 2020, 324, 1980-1991. [CrossRef] [PubMed]

87. Moura, N.M.M.; Ramos, C.I.V.; Linhares, I.; Santos, S.M.; Faustino, M.A.F.; Almeida, A.; Cavaleiro, J.A.S.; Amado, F.M.L.; Lodeiro, C.; Neves, M.G.P.M.S. Synthesis, characterization and biological evaluation of cationic porphyrin-terpyridine derivatives. RSC Adv. 2016, 6, 110674-110685. [CrossRef]

88. Moura, N.M.M.; Faustino, M.A.F.; Neves, M.G.P.M.S.; Paz, F.A.; Silva, A.; Tomé, A.C.; Cavaleiro, J.A.S. New synthetic approach to benzoporphyrins and Kröhnke type porphyrin-2-ylpyridines. Chem. Commun. 2012, 48, 6142. [CrossRef]

89. Moura, N.M.M.; Nuñez, C.; Santos, S.M.; Faustino, M.A.; Cavaleiro, J.; Neves, M.G.P.M.S.; Capelo, J.L.; Lodeiro, C. Functionalized Porphyrins as Red Fluorescent Probes for Metal Cations: Spectroscopic, MALDI-TOF Spectrometry, and Doped-Polymer Studies. ChemPlusChem 2013, 78, 1230-1243. [CrossRef]

90. Hashimoto, T.; Choe, Y.-K.; Nakano, A.H.; Hirao, K. Theoretical Study of the Q and B Bands of Free-Base, Magnesium, and Zinc Porphyrins, and Their Derivatives. J. Phys. Chem. A 1999, 103, 1894-1904. [CrossRef]

91. Maximiano, R.; Piovesan, E.; Zilio, S.; Machado, A.; De Paula, R.; Cavaleiro, J.A.S.; Borissevitch, I.; Ito, A.; Gonçalves, P.; Neto, N.B. Excited-state absorption investigation of a cationic porphyrin derivative. J. Photochem. Photobiol. A Chem. 2010, 214, 115-120. [CrossRef]

92. Baskin, J.S.; Yu, H.-Z.; Zewail, A.H. Ultrafast Dynamics of Porphyrins in the Condensed Phase: I. Free Base Tetraphenylporphyrint. J. Phys. Chem. A 2002, 106, 9837-9844. [CrossRef]

93. Ohno, O.; Kaizu, Y.; Kobayashi, H. Luminescence of some metalloporphins including the complexes of the IIIb metal group. J. Chem. Phys. 1985, 82, 1779-1787. [CrossRef]

94. Seybold, P.G.; Gouterman, M. Porphyrins. J. Mol. Spectrosc. 1969, 31, 1-13. [CrossRef]

95. Molinspiration Cheminformatics. The n-Octanol:Water Partition Coefficients (miLog P) Were Evaluated Using the MolinspirationWebME Editor 3.81. Available online: http:/ / www.molinspiration.com (accessed on 16 August 2021).

96. Isakau, H.; Parkhats, M.; Knyukshto, V.; Dzhagarov, B.; Petrov, E.; Petrov, P. Toward understanding the high PDT efficacy of chlorin e6-polyvinylpyrrolidone formulations: Photophysical and molecular aspects of photosensitizer-polymer interaction in vitro. J. Photochem. Photobiol. B Biol. 2008, 92, 165-174. [CrossRef]

97. Kashef, N.; Huang, Y.; Hamblin, M.R. Advances in antimicrobial photodynamic inactivation at the nanoscale. Nanophotonics 2017, 6, 853-879. [CrossRef] [PubMed]

98. Schwach-Abdellaoui, K.; Vivien-Castioni, N.; Gurny, R. Local delivery of antimicrobial agents for the treatment of periodontal diseases. Eur. J. Pharm. Biopharm. 2000, 50, 83-99. [CrossRef]

99. Cardoso, M.F.D.C.; Gomes, A.T.P.C.; Moreira, C.D.S.; Simões, M.M.Q.; Neves, M.G.P.M.S.; Da Rocha, D.R.; Silva, F.D.C.D.; Moreirinha, C.; Almeida, A.; Ferreira, V.F.; et al. Efficient Catalytic Oxidation of 3-Arylthio- and 3-Cyclohexylthio-lapachone Derivatives to New Sulfonyl Derivatives and Evaluation of Their Antibacterial Activities. Molecules 2017, 22, 302. [CrossRef]

100. Gomes, A.T.P.C.; Fernandes, R.; Ribeiro, C.F.; Tomé, J.P.C.; Neves, M.G.P.M.S.; Silva, F.D.C.D.; Ferreira, V.F.; Cavaleiro, J.A.S. Synthesis, Characterization and Photodynamic Activity against Bladder Cancer Cells of Novel Triazole-Porphyrin Derivatives. Molecules 2020, 25, 1607. [CrossRef] 
101. Tavares, A.; Carvalho, C.M.B.; Faustino, M.A.F.; Neves, M.G.P.M.S.; Tomé, J.P.C.; Tomé, A.C.; Cavaleiro, J.A.S.; Cunha, A.; Gomes, N.C.M.; Alves, E.; et al. Antimicrobial Photodynamic Therapy: Study of Bacterial Recovery Viability and Potential Development of Resistance after Treatment. Mar. Drugs 2010, 8, 91-105. [CrossRef] [PubMed]

102. Zimcik, P.; Miletin, M.; Radilova, H.; Novakova, V.; Kopecky, K.; Svec, J.; Rudolf, E. Synthesis, Properties andIn VitroPhotodynamic Activity of Water-soluble Azaphthalocyanines and Azanaphthalocyanines. Photochem. Photobiol. 2010, 86, 168-175. [CrossRef]

103. Spesia, M.B.; Milanesio, M.E.; Durantini, E.N. Synthesis, properties and photodynamic inactivation of Escherichia coli by novel cationic fullerene C60 derivatives. Eur. J. Med. Chem. 2008, 43, 853-861. [CrossRef]

104. Spiller, W.; Kliesch, H.; Wöhrle, D.; Hackbarth, S.; Röder, B.; Schnurpfeil, G. Singlet Oxygen Quantum Yields of Different Photosensitizers in Polar Solvents and Micellar Solutions. J. Porphyr. Phthalocyanines 1998, 2, 145-158. [CrossRef]

105. Zenkevich, E.; Sagun, E.; Knyukshto, V.; Shulga, A.; Mironov, A.F.; Efremova, O.; Bonnett, R.; Songca, S.P.; Kassem, M. Photophysical and photochemical properties of potential porphyrin and chlorin photosensitizers for PDT. J. Photochem. Photobiol. B Biol. 1996, 33, 171-180. [CrossRef]

106. De Almeida, D.R.Q.; Terra, L.F.; Labriola, L. Photodynamic therapy in cancer treatment-An update review. J. Cancer Metastasis Treat. 2019, 5, 25. [CrossRef] 